\title{
Secondary organic aerosol formation in biomass-burning plumes: theoretical analysis of lab studies and ambient plumes
}

\author{
Qijing Bian ${ }^{1}$, Shantanu H. Jathar ${ }^{2}$, John K. Kodros ${ }^{1}$, Kelley C. Barsanti ${ }^{3}$, Lindsay E. Hatch ${ }^{3}$, Andrew A. May ${ }^{4}$, \\ Sonia M. Kreidenweis ${ }^{1}$, and Jeffrey R. Pierce ${ }^{1,5}$ \\ ${ }^{1}$ Department of Atmospheric Science, Colorado State University, Fort Collins, CO, USA \\ ${ }^{2}$ Department of Mechanical Engineering, Colorado State University, Fort Collins, CO, USA \\ ${ }^{3}$ Department of Chemical and Environmental Engineering and College of Engineering, Center for Environmental \\ Research and Technology (CE-CERT), University of California, Riverside, CA, USA \\ ${ }^{4}$ Department of Civil, Environmental and Geodetic Engineering, the Ohio State University, Columbus, OH, USA \\ ${ }^{5}$ Department of Physics and Atmospheric Science, Dalhousie University, Halifax, NS, Canada \\ Correspondence to: Jeffrey R. Pierce (jeffrey.pierce@ colostate.edu)
}

Received: 25 October 2016 - Discussion started: 1 November 2016

Revised: 21 January 2017 - Accepted: 30 March 2017 - Published: 28 April 2017

\begin{abstract}
Secondary organic aerosol (SOA) has been shown to form in biomass-burning emissions in laboratory and field studies. However, there is significant variability among studies in mass enhancement, which could be due to differences in fuels, fire conditions, dilution, and/or limitations of laboratory experiments and observations. This study focuses on understanding processes affecting biomass-burning SOA formation in laboratory smog-chamber experiments and in ambient plumes. Vapor wall losses have been demonstrated to be an important factor that can suppress SOA formation in laboratory studies of traditional SOA precursors; however, impacts of vapor wall losses on biomass-burning SOA have not yet been investigated. We use an aerosol-microphysical model that includes representations of volatility and oxidation chemistry to estimate the influence of vapor wall loss on SOA formation observed in the FLAME III smogchamber studies. Our simulations with base-case assumptions for chemistry and wall loss predict a mean OA mass enhancement (the ratio of final to initial OA mass, corrected for particle-phase wall losses) of 1.8 across all experiments when vapor wall losses are modeled, roughly matching the mean observed enhancement during FLAME III. The mean OA enhancement increases to over 3 when vapor wall losses are turned off, implying that vapor wall losses reduce the apparent SOA formation. We find that this decrease in the apparent SOA formation due to vapor wall losses is robust across the ranges of uncertainties in the key model assump-
\end{abstract}

tions for wall-loss and mass-transfer coefficients and chemical mechanisms.

We then apply similar assumptions regarding SOA formation chemistry and physics to smoke emitted into the atmosphere. In ambient plumes, the plume dilution rate impacts the organic partitioning between the gas and particle phases, which may impact the potential for SOA to form as well as the rate of SOA formation. We add Gaussian dispersion to our aerosol-microphysical model to estimate how SOA formation may vary under different ambient-plume conditions (e.g., fire size, emission mass flux, atmospheric stability). Smoke from small fires, such as typical prescribed burns, dilutes rapidly, which drives evaporation of organic vapor from the particle phase, leading to more effective SOA formation. Emissions from large fires, such as intense wildfires, dilute slowly, suppressing OA evaporation and subsequent SOA formation in the near field. We also demonstrate that different approaches to the calculation of OA enhancement in ambient plumes can lead to different conclusions regarding SOA formation. OA mass enhancement ratios of around 1 calculated using an inert tracer, such as black carbon or $\mathrm{CO}$, have traditionally been interpreted as exhibiting little or no SOA formation; however, we show that SOA formation may have greatly contributed to the mass in these plumes.

In comparison of laboratory and plume results, the possible inconsistency of OA enhancement between them could be in part attributed to the effect of chamber walls and plume 
dilution. Our results highlight that laboratory and field experiments that focus on the fuel and fire conditions also need to consider the effects of plume dilution or vapor losses to walls.

\section{Introduction}

Biomass burning is an important source of carbonaceous compounds that have significant influence on air quality (Jaffe and Widger, 2012), climate (Bond et al., 2013), and human health (Naeher et al., 2007; Jassen, 2012; Johnston et al., 2012). It is a major source of primary fine carbonaceous (black and organic carbon) particles (Akagi et al., 2011), but the contribution of biomass burning to ambient concentrations of secondary organic aerosol (SOA, organic aerosol (OA) formed in the atmosphere) is highly variable because of the complexities of physical and chemical evolution of biomass-burning plumes. Laboratory studies have observed both significant OA increase and OA decrease in biomass-burning emissions (Hennigan et al., 2011; Ortega et al., 2013). Some field studies of biomass burning also observed OA formation (Yokelson et al., 2009) and some showed little OA production or even a net loss (Akagi et al., 2012; Capes et al., 2008; May et al., 2015). OA loss was approximately $50 \%$ in first hour after emission in the study of May et al. (2015). OA consists of thousands of species, but only a small portion of these have been identified, and thus understanding of phase partitioning and the chemistry occurring in biomass-burning emissions is still poor (Heilman et al., 2014).

The semivolatile nature of biomass-burning primary organic aerosol (POA) as identified in recent studies (Grieshop et al., 2009; May et al., 2013) further complicates the phase dynamics during the evolution of biomass-burning emissions, both in the laboratory and in ambient air. In an ambient plume, positive impacts on emitted OA mass could occur by the condensation of low-volatile organics produced from the oxidation of volatile and semivolatile organics (Yokelson et al., 2009), while reductions in OA mass could occur due to evaporation of organic vapors driven by dilution (Jolleys et al., 2012) or by fragmentation reactions creating highervolatility species. Hence, observations of OA evolution in the field are always influenced by plume dilution and complex chemical pathways that compete for OA enhancement and loss (Akagi et al., 2012; May et al., 2015) and it is difficult to observationally separate those effects. An extensive literature search reveals little work exploring how fire conditions (e.g., fire size and mass flux) and atmospheric stability conditions (e.g., unstable or stable) affect OA evolution in a chemically evolving plume and how those factors would influence the observed plume characteristics.

To reduce some of the complexity inherent in ambient observations, smog chambers are widely used to study the evo- lution of organic aerosol. The mechanism of particle wall loss has been well studied (Crump and Seinfeld, 1981; McMurry and Rader, 1985; Pierce et al., 2008) and is commonly used to correct aerosol measurements in smog-chamber studies (Weitkamp et al., 2007; Hennigan et al., 2011). Wall loss of organic vapors may also be important and leads to impacts on gas-particle partitioning in chamber experiments, as has been demonstrated in recent studies (Matsunaga and Ziemann, 2010; Yeh and Ziemann, 2015; Zhang et al., 2015; Bian et al., 2015; Krechmer et al., 2016). Vapor uptake to Teflon chamber walls demonstrates absorptive partitioning behavior following Henry's law. The resulting loss of SOA precursors to chamber walls makes them unavailable for reaction and leads to underestimates of SOA production in chamber studies (Matsunaga and Ziemann, 2010; Yeh and Ziemann, 2015; Zhang et al., 2014, 2015). Zhang et al. (2014) predicted that vapor wall losses in a $25 \mathrm{~m}^{3}$ chamber may lead to factor-of-4 underestimates of SOA mass formation from biogenic and anthropogenic precursor vapors. Kokkola et al. (2014) also showed that SOA formation from ozonolysis of $\alpha$-pinene may be underestimated by a factor of up to 4 in a $4 \mathrm{~m}^{3}$ chamber. Based on the work of Lim and Ziemann (2009) and Matsunaga and Ziemann (2010), La et al. (2016) suggested that SOA yield from mixtures of alkanes, alkenes and alcohols, or ketones may be underestimated by a factor of 2 in chambers of volumes of 5.9 and $1.7 \mathrm{~m}^{3}$. Cappa et al. (2016) estimated that SOA was increased by factors of $\sim 2-10$, depending on scenario, when vapor wall losses were accounted for in air quality model simulations. However, it has also been pointed out that increasing seed surface area could effectively compete for vapor absorption, suppressing vapor wall losses and increasing SOA formation in chamber studies (Zhang et al., 2014; McVay et al., 2014). Nah et al. (2016) also observed that the effects of vapor wall deposition on SOA mass yields could be constrained if vapor condensation occurs under quasi-equilibrium growth (i.e., the particles and vapors reach equilibrium quickly).

Several modeling studies have examined SOA formation in ambient air from biomass-burning emissions (Mason et al., 2001; Alvarado and Prinn, 2009; Alvarado et al., 2015). One difficulty is that the compounds that act as precursors of SOA in biomass-burning emissions are not well understood. Including only known SOA precursors (mainly aromatic species like toluene) in the model largely underestimates SOA production, probably because of limited knowledge about additional SOA-precursor vapors, such as intermediate-volatility organic compounds (IVOCs; Alvarado and Prinn, 2009; Jathar et al., 2014). Alvarado et al. (2015) included assumptions of unidentified IVOCs, semivolatile and extremely-low-volatility organic compounds in the modeling of $\mathrm{OA}$ and $\mathrm{O}_{3}$ formation and successfully reproduced ambient observations. However, their study did not consider the specific impacts of vapor wall losses on laboratory observations of biomass-burning SOA and how this might constrain SOA formation chemistry. 


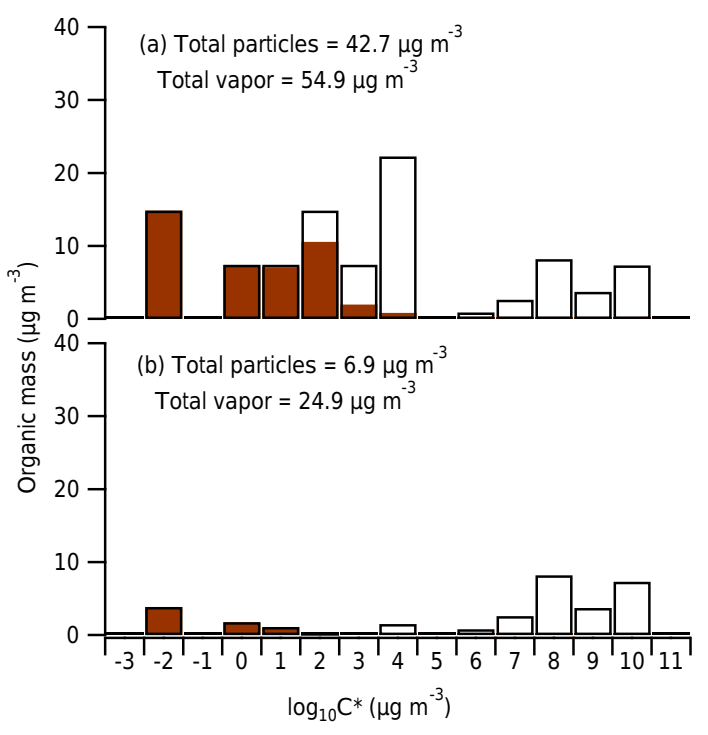

Figure 1. (a) Volatility distribution with 15 volatility bins, adapted from the work of May et al. (2013) and Hatch et al. (2017). The average total initial organic aerosol mass concentration is $42.7 \mu \mathrm{g} \mathrm{m}^{-3}$ over the 18 experiments. For this mass concentration, the shaded area represents the organic mass in the particulate phase in each volatility bin. (b) The simulated volatility distribution without chemistry after $4 \mathrm{~h}$ of particle and vapor wall loss. The concentrations are the means across all 18 experiments.

Further, dilution effects on SOA formation during plume transport have not yet been investigated. In previous work, Bian et al. (2015) showed that organic-vapor wall loss in Teflon chamber experiments may drive evaporation of primary biomass-burning organic aerosol; however, the resulting impacts on SOA formation were not investigated in that work.

In this study, we (1) investigate the influence of vapor wall loss on biomass-burning SOA formation in a smog chamber, based on current knowledge of particle and vapor-wall-loss rates, and (2) explore the effect of dilution on SOA formation in ambient plumes. For the smog-chamber portion of this work, we use an aerosol-microphysical model that includes particle/vapor wall losses and SOA chemistry to simulate observations reported in Hennigan et al. (2011) from smogchamber experiments conducted in the third Fire Lab At Missoula Experiment (FLAME III). For the ambient-plume portion of this work, we add Gaussian dispersion to the aerosolmicrophysics-chemistry model and perform sensitivity simulations that capture the effects of fire size, variable mass flux, and atmospheric stability.

\section{Methods}

\subsection{Smog-chamber simulations}

Wood-smoke primary organic aerosol partitioning and SOA formation were investigated for the smog-chamber experiments conducted during the FLAME III study from September-October 2009 (Hennigan et al., 2011; May et al., 2013, 2014; Ortega et al., 2013; Bian et al., 2015). Eighteen fuels that frequently burn in wild or prescribed fires across North America were studied (Table 1). In each experiment, the combustion emissions were introduced into the smog chamber at a dilution ratio of $\sim 25: 1$ (relative to the USDA/USFS Fire Sciences Laboratory, FSL, combustion chamber). Photo-oxidation was initiated for 3-4.5 h using sunlight/UV light after a $75 \mathrm{~min}$ dark period during which primary gas and particle concentrations were characterized in the smog chamber. Additional experimental details are included in Hennigan et al. (2011), May et al. (2013), and Bian et al. (2015).

For our smog-chamber simulations, we use the TwOMoment Aerosol Sectional (TOMAS) microphysics model (Adams and Seinfeld, 2002; Pierce and Adams, 2009; Pierce et al., 2011) combined with particle and vapor-wall-loss algorithms and a SOA production matrix to estimate SOA formation for the 18 FLAME III experiments considered in Bian et al. (2015). Simulated aerosol species include black carbon (BC), organics, and water with 36 logarithmically spaced size sections from $3 \mathrm{~nm}$ to $10 \mu \mathrm{m}$. We assume that all species are internally mixed within each size section, meaning that the ratio of $\mathrm{BC}$ and $\mathrm{OA}$ are the same for all particles within each size bin. When calculating OA partitioning, we assume that $\mathrm{OA}$ and $\mathrm{BC}$ exist in separate phases, and thus this presence of $\mathrm{BC}$ does not influence $\mathrm{OA}$ partitioning to the particle phase in the model. In our previous study examining the influence of wall loss on primary semivolatile organics in the chamber (Bian et al., 2015), we simulated eight organic "species" within the Volatility Basis Set (Donahue et al., 2006) with logarithmically spaced effective saturation concentrations $\left(C^{*}\right)$ spanning from $10^{-3}$ to $10^{4} \mu \mathrm{g} \mathrm{m}^{-3}$ using the volatility distribution derived by May et al. (2013). $C^{*}$ of $10^{4} \mathrm{\mu g} \mathrm{m}^{-3}$ is the least-constrained volatility bin in the analysis of May et al. (2013), and the large amount of material in this bin may represent some of the vapor in higher bins. In this current study, we expand the simulated organics from 8 to 15 "species" including more volatile organics between $10^{6}$ and $10^{11} \mathrm{\mu g} \mathrm{m}^{-3}$, based on the FLAME-4 study of Hatch et al. (2017) to account for chemical transformations from both volatile and semivolatile organic species and estimate the initial organic-vapor concentration based on aerosol partitioning theory (Pankow, 1994) on the assumption of gas and particle equilibrium partitioning (Fig. 1a). The evolution of the organic vapors is calculated based on partitioning theory (to get equilibrium vapor pressures above the particle), wall-equilibrium vapor pressures, and kinetic mass transfer 
Table 1. Data for 18 wood-smoke samples introduced to the smog chamber, including fuel types, initial number concentration, and corresponding size distribution parameters (median diameter in $\mathrm{nm}$ and geometric standard deviation, $\sigma$ ), initial total aerosol nonrefractory mass concentration, the organic mass fraction of the aerosol phase, and $\mathrm{OH}$ exposure rate. The Burn ID and $\mathrm{OH}$ exposure refer to the schedule of burns in FLAME III, as reported in Hennigan et al. (2011).

\begin{tabular}{|c|c|c|c|c|c|c|c|c|c|c|}
\hline \multirow[b]{2}{*}{$\begin{array}{l}\text { Burn } \\
\text { ID }\end{array}$} & \multirow[b]{2}{*}{ Fuel type } & \multirow[b]{2}{*}{$\begin{array}{r}\text { Temp } \\
(\mathrm{K})\end{array}$} & \multirow[b]{2}{*}{$\begin{array}{r}\text { Initial } \\
\text { particle } \\
\text { number } \\
\text { concentration } \\
\left(\mathrm{cm}^{-3}\right)\end{array}$} & \multicolumn{2}{|c|}{ No. size dist. } & \multirow[b]{2}{*}{$\begin{array}{r}\text { Initial total } \\
\text { mass } \\
\text { concentration }{ }^{1} \\
\left(\mu \mathrm{g} \mathrm{m}^{-3}\right)\end{array}$} & \multirow[b]{2}{*}{$\begin{array}{r}\text { Organic } \\
\text { mass } \\
\text { fraction }^{2}\end{array}$} & \multirow[b]{2}{*}{$\begin{array}{l}k_{\mathrm{w}, \mathrm{p} 0} \\
\left(\mathrm{~s}^{-1}\right)\end{array}$} & \multirow[b]{2}{*}{$\begin{array}{r}k_{\mathrm{e}} \\
\left(\mathrm{s}^{-1}\right)\end{array}$} & \multirow[b]{2}{*}{$\begin{array}{r}\text { OH exposure } \\
\text { (molecules } \\
\left.\mathrm{cm}^{-3} \mathrm{~s}\right)\end{array}$} \\
\hline & & & & $\begin{array}{r}\text { Median } \\
\text { diameter } \\
(\mathrm{nm})\end{array}$ & $\sigma$ & & & & & \\
\hline 37 & Lodgepole Pine & 292.9 & 5843 & 157 & 1.73 & 44.96 & 0.943 & $8.03 \times 10^{-5}$ & 1.07 & $1.56 \times 10^{10}$ \\
\hline 38 & Lodgepole Pine & 286.8 & 7612 & 127 & 1.67 & 40.96 & 0.896 & $6.27 \times 10^{-5}$ & 1.41 & $1.40 \times 10^{10}$ \\
\hline 40 & Ponderosa Pine & 279.5 & 6505 & 160 & 1.84 & 63.73 & 0.954 & $8.67 \times 10^{-5}$ & 0.69 & $2.71 \times 10^{10}$ \\
\hline 42 & Wire Grass & 277.0 & 8107 & 123 & 1.55 & 19.63 & 0.484 & $1.07 \times 10^{-4}$ & 0.77 & $3.50 \times 10^{10}$ \\
\hline 43 & Saw Grass & 284.2 & 5406 & 123 & 1.73 & 18.16 & 0.347 & $1.07 \times 10^{-4}$ & 0.52 & $3.10 \times 10^{10}$ \\
\hline 45 & Turkey Oak & 286.3 & 6334 & 106 & 1.63 & 16.80 & 0.506 & $8.11 \times 10^{-5}$ & 0.99 & $2.09 \times 10^{10}$ \\
\hline 47 & Gallberry & 286.7 & 8265 & 123 & 1.61 & 39.16 & 0.881 & $7.37 \times 10^{-5}$ & 0.19 & $6.12 \times 10^{10}$ \\
\hline 49 & Sage & 285.0 & 5486 & 127 & 1.71 & 17.76 & 0.321 & $8.84 \times 10^{-5}$ & 0.84 & $1.84 \times 10^{10}$ \\
\hline 51 & Alaskan Duff & 282.5 & 4175 & 88 & 1.83 & 20.38 & 0.898 & $7.00 \times 10^{-5}$ & 0.32 & ${ }^{3} 4.29 \times 10^{10}$ \\
\hline 53 & Sage & 287.2 & 5619 & 132 & 1.76 & 16.09 & 0.348 & $8.43 \times 10^{-5}$ & 0.91 & ${ }^{3} 4.29 \times 10^{10}$ \\
\hline 55 & White Spruce & 281.6 & 4641 & 115 & 1.83 & 27.73 & 0.761 & $8.13 \times 10^{-5}$ & 0.31 & $6.59 \times 10^{10}$ \\
\hline 57 & Ponderosa Pine & 277.9 & 6624 & 161 & 1.81 & 72.83 & 0.935 & $8.43 \times 10^{-5}$ & 0.96 & $7.99 \times 10^{10}$ \\
\hline 59 & Chamise & 281.9 & 7173 & 148 & 1.79 & 24.89 & 0.221 & $7.58 \times 10^{-5}$ & 0.83 & $4.95 \times 10^{10}$ \\
\hline 61 & Lodgepole Pine & 283.1 & 6059 & 153 & 1.79 & 63.03 & 0.944 & $6.30 \times 10^{-5}$ & 0.29 & $7.89 \times 10^{10}$ \\
\hline 63 & Pocosin & 277.9 & 7463 & 112 & 1.65 & 26.20 & 0.603 & $8.46 \times 10^{-5}$ & 0.37 & $8.22 \times 10^{10}$ \\
\hline 65 & Gallberry & 275.3 & 7763 & 159 & 1.68 & 85.98 & 0.899 & $1.43 \times 10^{-4}$ & 0.62 & $4.94 \times 10^{10}$ \\
\hline 66 & Black Spruce & 279.0 & 9828 & 96 & 1.66 & 35.21 & 0.852 & $1.02 \times 10^{-4}$ & 0.36 & $2.63 \times 10^{10}$ \\
\hline 67 & Wire Grass & 274.5 & 11580 & 129 & 1.52 & 36.51 & 0.619 & $5.78 \times 10^{-5}$ & 0.28 & $3.06 \times 10^{10}$ \\
\hline
\end{tabular}

${ }^{1}$ Total mass $=[\mathrm{OA}]+\left[\mathrm{SO}_{4}^{2-}\right]+\left[\mathrm{NO}_{3}^{-}\right]+\left[\mathrm{NH}_{4}^{+}\right]+\left[\mathrm{Cl}^{-}\right]+[\mathrm{BC}]$, total aerosol nonrefractory mass concentration as measured by the Aerodyne quadruple aerosol mass spectrometer; black carbon was determined by a seven-channel Aethalometer at $880 \mathrm{~nm} .{ }^{2}$ Organic fraction $=[\mathrm{OA}] /\left([\mathrm{OA}]+\left[\mathrm{SO}_{4}^{2-}\right]+\left[\mathrm{NO}_{3}^{-}\right]+\left[\mathrm{NH}_{4}^{+}\right]+\left[\mathrm{Cl}^{-}\right]+\left[\mathrm{BC}^{-}\right) .{ }^{3} \mathrm{We}\right.$ have assumed the average $\mathrm{OH}$ exposure of the other 16 experiments, as no $\mathrm{OH}$ exposure rate was provided for these two experiments.

to/from the particles and the walls. As described in Bian et al. (2015), we retrieved a representative turbulence rate $\left(k_{\mathrm{e}}, \mathrm{s}^{-1}\right.$; Crump and Seinfeld, 1981) by applying the aerosol parameter estimation (APE) model to the data of scanning mobility particle sizer following the method in Pierce et al. (2008). We then estimated the size-dependent particle wall-loss rates $\left(k_{\mathrm{w}, \mathrm{p}}\left(D_{\mathrm{p}}\right)\right.$, Eq. 1) and reversible vapor-wallloss rate coefficients ( $k_{\mathrm{w}, \text { on }}$ and $k_{\mathrm{w} \text {,off }}$, Eqs. 2 and 3$)$ using the fitted turbulence rate $\left(k_{\mathrm{e}}\right)$ :

$k_{\mathrm{w}, \mathrm{p}}\left(D_{\mathrm{p}}\right)=k_{\mathrm{w}, \mathrm{p} 0}+\frac{6 \sqrt{k_{\mathrm{e}} D}}{\pi R} D_{1}\left(\frac{\pi \gamma_{s}}{2 \sqrt{k_{\mathrm{e}} D}}\right)+\frac{v_{\mathrm{s}}}{4 R / 3}$,

$k_{\mathrm{w}, \text { on }}=\left(\frac{A}{V}\right) \frac{\left(\frac{\alpha_{\mathrm{w}} \bar{c}}{4}\right)}{1.0+\left(\frac{\pi}{2}\right)\left[\frac{\alpha_{\mathrm{w}} \bar{c}}{4\left(k_{\mathrm{e}} D_{\mathrm{gas}}\right)^{0.5}}\right]}$,

$k_{\mathrm{w}, \text { off }}=\frac{k_{\mathrm{w}, \text { on }}}{K_{w} C_{\mathrm{w}}}=k_{\mathrm{w}, \text { on }}\left(\frac{C^{*} M_{\mathrm{w}} \gamma_{\mathrm{w}}}{C_{\mathrm{w}} M_{\mathrm{p}} \gamma_{\mathrm{p}}}\right)$,

where $D$ is the Brownian diffusivity of the particle of size $D_{\mathrm{p}}, R$ is the radius of the chamber on the assumption that the chamber is a sphere, $v_{\mathrm{s}}$ is the gravitational settling velocity of the particle, and $k_{\mathrm{w}, \mathrm{p} 0}$ is a size-independent wall-loss rate that is used to represent the effect of electrostatic forces on the wall loss. $D_{1}$ is the Debye function (Abramowitz and Stegun, 1964). The fitted values of $k_{\mathrm{e}}$ and $k_{\mathrm{w}, \mathrm{p} 0}$ are listed in Table 1. $k_{\mathrm{w}, \text { on }}$ is the rate coefficient for the transfer of gas-phase organic vapors to the wall, $A / V$ is the surface to volume ratio of the chamber, $\alpha_{\mathrm{w}}$ is the mass accommodation coefficient of vapors onto the chamber walls, $\left(\mathrm{m} \mathrm{s}^{-1}\right)$ is the mean thermal speed of the molecules (calculated using the molecular weights of each organic volatility bin), $k_{\mathrm{e}}$ is a function of the turbulent kinetic energy in the chamber (derived from the APE model described above), and $D_{\text {gas }}$ is the molecular diffusivity $\left(\mathrm{m}^{2} \mathrm{~s}^{-1}\right) . k_{\mathrm{w}, \text { off }}$ is the evaporation rate coefficient from the wall. $K_{w}$ is the gas-particle partitioning coefficient. $C_{\mathrm{w}}$ is the equivalent or effective organic mass $(\mathrm{OM})$ concentration of the walls (in units of mass per chamber volume). $C^{*}$ is the saturation concentration $\left(\mu \mathrm{g} \mathrm{m}^{-3}\right) . M_{\mathrm{p}}$ and $M_{\mathrm{w}}$ are the average molecular weights of the organic species in the particles and in the Teflon film comprising the chamber $\left(\mu \mathrm{g} \mathrm{m}^{-3}\right) . \gamma_{\mathrm{w}}$ and $\gamma_{\mathrm{p}}$ are the activity coefficients of the organic species in the Teflon film and the particle phase, respectively. 
Table 2. Gas-phase chemistry volatility matrix that describes the change in volatility of the gas-phase organics after a single reaction with $\mathrm{OH}$. Labels a and b represent the cases with four- and two-volatility-bin drops per reaction, respectively.

\begin{tabular}{|c|c|c|c|c|c|c|c|c|c|c|c|c|c|}
\hline \multirow{2}{*}{$\begin{array}{l}\text { Precursor } \log _{10} C^{*} \\
\left(\mu \mathrm{g} \mathrm{m}^{-3}\right)\end{array}$} & \multicolumn{13}{|c|}{ Product $\log _{10} C^{*}\left(\mu \mathrm{g} \mathrm{m}^{-3}\right)$} \\
\hline & -3 & -2 & -1 & 0 & 1 & 2 & 3 & 4 & 5 & 6 & 7 & 8 & 9 \\
\hline-2 & $a, b$ & & & & & & & & & & & & \\
\hline-1 & $\mathrm{a}, \mathrm{b}$ & & & & & & & & & & & & \\
\hline 0 & $\mathrm{a}$ & $\mathrm{b}$ & & & & & & & & & & & \\
\hline 1 & $\mathrm{a}$ & & $\mathrm{b}$ & & & & & & & & & & \\
\hline 2 & & $\mathrm{a}$ & & $\mathrm{b}$ & & & & & & & & & \\
\hline 3 & & & $\mathrm{a}$ & & $b$ & & & & & & & & \\
\hline 4 & & & & $\mathrm{a}$ & & $b$ & & & & & & & \\
\hline 5 & & & & & $\mathrm{a}$ & & $\mathrm{b}$ & & & & & & \\
\hline 6 & & & & & & $\mathrm{a}$ & & $\mathrm{b}$ & & & & & \\
\hline 7 & & & & & & & $\mathrm{a}$ & & $\mathrm{b}$ & & & & \\
\hline 8 & & & & & & & & $\mathrm{a}$ & & $\mathrm{b}$ & & & \\
\hline 9 & & & & & & & & & $\mathrm{a}$ & & b & & \\
\hline 10 & & & & & & & & & & $\mathrm{a}$ & & $\mathrm{b}$ & \\
\hline 11 & & & & & & & & & & & $\mathrm{a}$ & & $\mathrm{b}$ \\
\hline
\end{tabular}

Previous studies have shown two variables primarily control vapor-wall-loss rates: the effective saturation of vapor with respect to the wall $\left(C_{\mathrm{w}} / M_{\mathrm{w}} \gamma_{\mathrm{w}}\right)$ and the accommodation coefficient for vapor into the wall $\left(\alpha_{\mathrm{w}}\right.$, Bian et al., 2015; Zhang et al., 2015). Matsunaga and Ziemann (2010) suggested $C_{\mathrm{w}} / M_{\mathrm{w}} \gamma_{\mathrm{w}}$ values of $9,20,50$, and $120 \mu$ mole m$^{-3}$ for $n$-alkanes, 1-alkenes, 2-ketones, and 2-alcohols, respectively. Krechmer et al. (2016) extended the vapor-wall-loss study of Matsunaga and Ziemann (2010) to species over a broader volatility range, suggesting that $C_{\mathrm{w}}$ be treated as a function of $C^{*}$. Zhang et al. (2015) also implied that $C_{\mathrm{w}}$ could depend on $C^{*}$, but their calculated $C_{\mathrm{w}}$ values were smaller than those recommended by Krechmer et al. (2016) for $C^{*}$ lower than $10^{5} \mu \mathrm{g} \mathrm{m}^{-3}$. For the mass accommodation coefficient of vapors on wall $\left(\alpha_{\mathrm{w}}\right)$, Matsunaga and Ziemann (2010) found it to be above $1 \times 10^{-5}$ while Zhang et al. (2015) found that $\alpha_{\mathrm{w}}$ is also dependent on $C^{*}$. In our simulations of the smog-chamber experiments that are presented here, we use the Krechmer $C_{\mathrm{w}} / M_{\mathrm{w}} \gamma_{\mathrm{w}}$ values and a $\alpha_{\mathrm{w}}$ of $1 \times 10^{-5}$ in the base-case simulations and then perform sensitivity tests by varying $C_{\mathrm{w}} / M_{\mathrm{w}} \gamma_{\mathrm{w}}$ and $\alpha_{\mathrm{w}}$ according to the range of previously reported values.

The gas-phase organic chemistry matrix used in the model follows the study of Jathar et al. (2014). We assume that only functionalization occurs in the biomass-burning experiments, with the product organic vapors having volatilities that are either two or four volatility bins lower than the parent (Table 2). We also do not include aerosol-phase or heterogeneous reactions, cloud processing, or effects of smoke on oxidant fields in our model, although these processes may affect the chemistry of plume (Yokelson et al., 2003; Akagi et al., 2011; Mok et al., 2016). The SOA mass yield $\alpha_{i, j}$ is assumed to be 1 for all reactions. We use this simple assumption of chemistry as a first test in our chamber and plume sys- tems as we found that we did not have enough information to constrain gas-phase yields or additional chemistry mechanisms beyond this. The chemical mechanism is represented as follows:

$$
\begin{aligned}
& \frac{\mathrm{d}\left[X_{j}\right]}{\mathrm{d} t}=-k_{\mathrm{OH}, X_{j}}[\mathrm{OH}]\left[X_{j}\right], \\
& \frac{\mathrm{d}\left[M_{i}\right]}{\mathrm{d} t}=\sum_{j} \alpha_{i, j} k_{\mathrm{OH}, X_{j}}[\mathrm{OH}]\left[X_{j}\right],
\end{aligned}
$$

where $\left[X_{j}\right]$ represents the concentration of a gas-phase species in volatility bin $\mathrm{j}, k_{\mathrm{OH}, x}$ is the reaction rate constant between the oxidant $\mathrm{OH}$ and the organic species $X_{j}$, and $\alpha_{i, j}$ is the mass yield of gaseous product $M_{i}$ in volatility bin $i$ (assumed to be 1 in our study). $\mathrm{OH}$ exposure ( $\mathrm{OH}$ concentration integrated over the time of the experiment) for each experiment is taken from Hennigan et al. (2011) and the average $\mathrm{OH}$ exposure across all of the experiments is assigned to the two experiments with missing values (Table 1). $\mathrm{OH}$ concentration $([\mathrm{OH}])$ is estimated on the assumption that the photochemical aging time in all the experiments was $4 \mathrm{~h} . k_{\mathrm{OH}}$ is computed from the mathematical relationship retrieved by Jathar et al. (2014) based on the data of Atkinson and Arey (2003): $k_{\mathrm{OH}}=-5.7 \times 10^{-12} \ln \left(C^{*}\right)+1.14 \times 10^{-10}$ for aromatics and $k_{\mathrm{OH}}=-1.84 \times 10^{-12} \ln \left(C^{*}\right)+4.27 \times 10^{-10}$ for alkanes. We use the fits for aromatics (faster chemistry) and alkanes (slower chemistry) separately in different simulations to provide bounds for the chemical reaction rates. As the relationships were derived from a limited number of species, we applied a minimum $k_{\mathrm{OH}}$ value to constrain the extrapolation to the broader volatility range, as these relationships give negative $k_{\mathrm{OH}}$ values at the highest-volatility bins. We then test the sensitivity of the OA enhancement ratios to the choice of minimum $k_{\mathrm{OH}}$ value of either $5 \times 10^{-12}$ 
or $1 \times 10^{-12}$. We do not consider condensed-phase chemistry in this study. The initial values of parameters used in the model simulations, including temperature, particle number concentration, number size distribution, mass concentration, and organic mass fraction, are listed in Table 1 for each experiment.

\subsection{Investigating $\mathrm{OA}$ in expanding plumes}

We apply a simple Gaussian dispersion framework to represent plume volume expansion in our box model. We assume that the pollutants are uniformly distributed within a box with a crosswind width of $y \pm 2 \sigma_{y}$ and height $z \pm 2 \sigma_{z}$ (the thickness of the box in the wind direction is fixed at $1 \mathrm{~m}$ ), so that the plume volume in the simulation is $4 \sigma_{y} \times 4 \sigma_{y} \times 1 \mathrm{~m}^{3}$. We assume that the initial plume width $\left(\sigma_{y}\right)$ is the same as the fire width (the square root of the fire area). The maximum plume height $\left(\sigma_{z}\right)$ is constrained by the boundary-layer depth, which is set to be $2500 \mathrm{~m}$, equivalent to a $\sigma_{z}$ of $625 \mathrm{~m}$. We perform sensitivity tests for fire areas of $1 \times 10^{-4}, 1 \times 10^{-2}$, 1 and $1 \times 10^{2} \mathrm{~km}^{2}$ (equivalent initial $\sigma_{y}$ of $2.5,25,250$, and $2500 \mathrm{~m}$, respectively) for a neutral atmospheric stability class (D) and an emission mass flux of $5 \times 10^{-6} \mathrm{~kg} \mathrm{~m}^{-2} \mathrm{~s}^{-1}$ (on the larger end of the fluxes in the GFED4 emission inventory as found by Sakamoto et al., 2016). The smallest fire size $\left(1 \times 10^{-4} \mathrm{~km}^{2}\right)$ was selected to represent a prescribed fire and the larger fire sizes $\left(1\right.$ and $\left.1 \times 10^{2} \mathrm{~km}^{2}\right)$ represent wildfire sources. For a fire size of $1 \mathrm{~km}^{2}$, we also test the sensitivity to atmospheric stability class (A, unstable; D, neutral; and F, stable) for mass fluxes of $2 \times 10^{-8}$ and $5 \times 10^{-6} \mathrm{~kg} \mathrm{~m}^{-2} \mathrm{~s}^{-1}$. The dispersion parameters used to estimate $\sigma_{y}$ and $\sigma_{z}$ for different Pasquill stability classes are taken from Klug (1969). The background is considered to be nonvolatile OA with a fixed concentration of $5 \mu \mathrm{g} \mathrm{m}^{-3}$, and this aerosol is entrained into the box as it expands. The organic-vapor chemistry scheme is the same as used in the chamber study. The input parameters for the TOMAS Gaussian dispersion dilution simulations are listed in Table 3.

\subsection{Definitions of OA enhancement}

We use two definitions of the "observed" OA enhancement ratio, both found in the literature, to demonstrate that these definitions impact the amount of apparent SOA formation in chambers and in plumes. In smog-chamber and field studies of biomass burning, the OA mass enhancement ratio is often calculated as the change in OA mass relative to the background and also relative to a species assumed to be inert on the experimental timescales. A commonly reported variable is the normalized excess mixing ratio (NEMR; Akagi et al., 2012), where the in-plume OA concentrations are corrected for background concentrations and normalized to an inert tracer (IT) also emitted from the fire (e.g., $\mathrm{CO}$ or BC):

$\mathrm{NEMR}_{t}=\frac{\left(\mathrm{OA}_{\text {in }}-\text { plume } / \text { chamber }, t-\mathrm{OA}_{\text {background }}\right)}{\left(\mathrm{IT}_{\text {in }}-\text { plume } / \text { chamber }, t-\mathrm{IT}_{\text {background }}\right)}$, where $t$ denotes that NEMR is a time-dependent (equivalently, downwind-distance-dependent) variable. If the OA and IT are nonreactive and non-depositing (or depositing at the same rate) and OA is nonvolatile, then NEMR remains unchanged with time and represents the emitted ratio of the two species, specific to the fuel and combustion conditions; as such, it can be compared with lab studies aimed at quantifying these emission ratios (e.g., May et al., 2014). In the case of smog-chamber experiments, the OA and IT background concentrations are negligible because the chamber is filled with clean air before injecting emissions. In this work, we use BC mass as our IT (Grieshop et al., 2009; Hennigan et al., 2011). We further normalize $\mathrm{NEMR}_{t}$ by the initial NEMR value (at the start of the lab experiments or at emission for the expanding plumes) to define the inert OA mass enhancement ratio (OAER inert $_{\text {i }}$ Eq. 7$)$ :

$\mathrm{OAER}_{\text {inert }}=\frac{\mathrm{NEMR}_{t}}{\mathrm{NEMR}_{0}}$.

The subscript 0 refers to values at the initial time, and the subscript $t$ refers to any subsequent time in the simulations or observations. As BC concentration decreases due to particlephase wall losses (in smog chambers) and dilution (in ambient plumes), $\mathrm{OAER}_{\text {inert }}$ normalizes the relative change in $\mathrm{OA}$ by the decrease in concentration of $\mathrm{BC}$ and thus corrects for particle-phase wall losses and dilution. If these are the only processes occurring, then $\mathrm{OAER}_{\text {inert }}$ remains fixed at a value of 1 at any time $t$. Other situations result in time-dependent $\mathrm{OAER}_{\text {inert }}$. Net $\mathrm{OA}$ production leads to $\mathrm{OAER}_{\text {inert }}$ values greater than 1 , and net OA evaporation leads to OAER inert

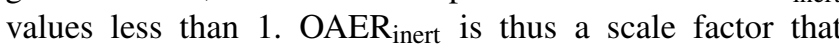
can be applied to OA emission factors to account for timedependent in-plume net production and/or loss of OA.

Although OAER $_{\text {inert }}$ can be computed readily from observations and can indicate when other processes besides dilution are active, POA evaporation and SOA production may compensate for each other, making it impossible to quantify the impact of SOA production through OAER $_{\text {inert }}$ (or NEMR) alone, as has been pointed out previously (e.g., DeCarlo et al., 2010; Akagi et al., 2012; May et al., 2015). To isolate the impact of chemistry alone on our simulations, we introduce the chemistry OA mass enhancement ratio $\left(\mathrm{OAER}_{\text {chem }}\right)$ to give an alternate metric of OAER inert $_{\text {, }}$, which is the convolution of evaporation and SOA formation. We define $\mathrm{OAER}_{\text {chem }}$ as the ratio of predicted OA concentrations in the chemistry-on and chemistry-off simulations:

$$
\mathrm{OAER}_{\text {chem }}=\left(\mathrm{OA}_{\text {chem on }, t}-\mathrm{OA}_{\text {background }}\right) /
$$$$
\left(\mathrm{OA}_{\text {chem off }, t}-\mathrm{OA}_{\text {background }}\right) \text {. }
$$

While OAER $\mathrm{R}_{\text {chem }}$ is not calculable from field or laboratory observations, it is the indicator of how SOA production enhances $\mathrm{OA}$ in the model, with all other processes being equal. 
Table 3. Input parameters for the ambient-plume Gaussian dispersion simulations.

\begin{tabular}{|c|c|c|}
\hline Parameter & Description & Value \\
\hline$D_{\mathrm{p}}$ & Emission particle dry diameter, $\mu \mathrm{m}$ & 0.157 \\
\hline$\sigma$ & $\begin{array}{l}\text { Emission particle size distribution } \\
\text { standard deviation }\end{array}$ & 1.7 \\
\hline$k_{\mathrm{OH}}$ & Ambient reaction rate constant, $\mathrm{cm}^{3}$ molecule ${ }^{-1} \mathrm{~s}^{-1}$ & $\begin{array}{l}\text { upper: }-5.70 \times 10^{-12} \ln \left(C^{*}\right)+1.14 \times 10^{-10} \\
\text { lower: }-1.84 \times 10^{-12} \ln \left(C^{*}\right)+4.27 \times 10^{-10}\end{array}$ \\
\hline$[\mathrm{OH}]$ & Ambient $\mathrm{OH}$ concentration, molecules $\mathrm{cm}^{-3}$ & $1.08 \times 10^{6}$ \\
\hline Mass flux & Emission mass flux from fire, $\mathrm{kg} \mathrm{m}^{-2} \mathrm{~s}^{-1}$ & $2 \times 10^{-8}, 5 \times 10^{-6}$ \\
\hline Fire area & Fire emissions area, $\mathrm{km}^{2}$ & $1 \times 10^{2}, 1,1 \times 10^{-2}, 1 \times 10^{-4}$ \\
\hline Wind speed & Mean boundary-layer wind speed, $\mathrm{ms}^{-1}$ & 5 \\
\hline Stability class & $\begin{array}{l}\text { Pasquill stability classes for } \\
\text { atmospheric turbulence }\end{array}$ & $\mathrm{A}, \mathrm{D}, \mathrm{F}$ \\
\hline Boundary height & Mean boundary height, $\mathrm{m}$ & 2500 \\
\hline$T$ & Ambient temperature during dilution, $\mathrm{K}$ & 298 \\
\hline Mass $_{b g}$ & Background aerosol mass concentration, $\mu \mathrm{g} \mathrm{m}^{-3}$ & 5.0 \\
\hline$D_{\mathrm{p}, \mathrm{bg}}$ & Dry diameter of background particles, $\mu \mathrm{m}$ & 0.3 \\
\hline$\sigma_{\mathrm{p}, \mathrm{bg}}$ & $\begin{array}{l}\text { Geometric standard deviation of size distribution } \\
\text { of background particles, } \mu \mathrm{m}\end{array}$ & 1.8 \\
\hline
\end{tabular}

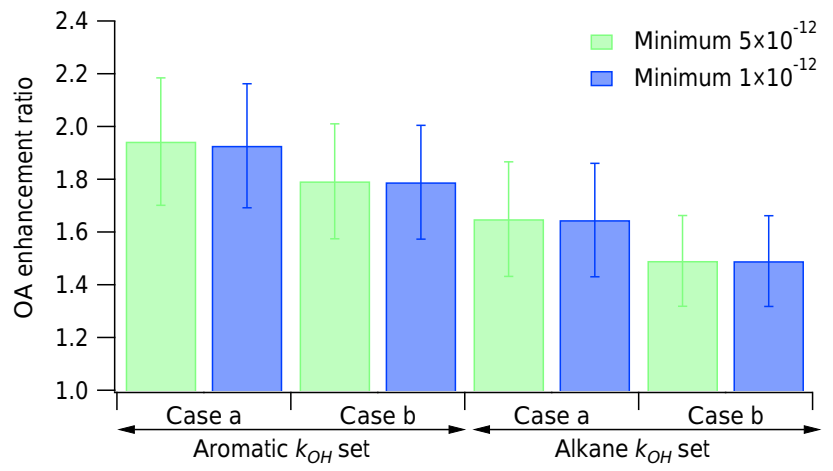

Figure 2. $\mathrm{OA}$ enhancement ratios $\left(\mathrm{OAER}_{\text {inert }}\right.$ and $\mathrm{OAER}_{\mathrm{chem}}$ are equivalent in these simulations), in the absence of particle and vapor wall losses, averaged over the 18 experimental simulations using $k_{\mathrm{OH}}$ sets fitted for aromatics and alkanes with a four-volatility-bin drop per reaction (Case a) and a two-volatility-bin drop per reaction (Case b). The minimum $k_{\mathrm{OH}}$ value is set to be $5 \times 10^{-12}$ (green bars) and $1 \times 10^{-12}$ (blue bars) $\mathrm{cm}^{3}$ mole $^{-1} \mathrm{~s}^{-1}$, respectively. The error bars represent 1 standard deviation across the 18 simulations and represent experiment-to-experiment variability.

\section{Results and discussions}

\subsection{Simulated chamber SOA production in absence of particle and vapor wall losses}

We test the sensitivity of $\mathrm{OA}$ to our assumed $k_{\mathrm{OH}}$ values and the drop in volatility of organic product species (relative to the parent compound) with each reaction with $\mathrm{OH}$ as described in Table 2.

Figure 2 shows the OA enhancement ratios for the chemistry sensitivity cases. In these simulations, OAER inert $_{\text {and }}$
OAER $_{\text {chem }}$ are equivalent as chemistry is the only process affecting OA mass (no wall losses or dilution), so the OA enhancement ratios in Fig. 2 represent both OAERs described above. The starting volatility distribution in these simulations are shown in Fig. 1a. Each bar in Fig. 2 is the OA enhancement ratio averaged over simulations of all 18 experiments. The predicted OA enhancements are insensitive to the chosen minimum $k_{\mathrm{OH}}$ values (i.e., $5 \times 10^{-12}$ and $1 \times 10^{-12} \mathrm{~cm}^{3} \mathrm{molec}^{-1} \mathrm{~s}^{-1}$ ); the difference in OA enhancement ratios for these choices is less than $1 \%$. We therefore use a minimum value of $5 \times 10^{-12} \mathrm{~cm}^{3} \mathrm{molec}^{-1} \mathrm{~s}^{-1}$ throughout the rest of this study. The OA enhancement ratio for the four-volatility-bin drop assumption, Case A $(1.9 \pm 0.2$ for aromatic $k_{\mathrm{OH}}$ set and $1.6 \pm 0.2$ for alkane $k_{\mathrm{OH}}$ set), is slightly larger than for the case assuming a two-volatility-bin drop, Case B $\left(1.8 \pm 0.2\right.$ for aromatic $k_{\mathrm{OH}}$ set and $1.5 \pm 0.2$ alkane $k_{\mathrm{OH}}$ set). The $\mathrm{OA}$ enhancement ratios simulated using the aromatic $k_{\mathrm{OH}}$ set are larger than those using the alkane $k_{\mathrm{OH}}$ set, because $k_{\mathrm{OH}}$ for aromatics is generally larger than alkanes when $C^{*}$ is lower than $10^{8} \mu \mathrm{g} \mathrm{m}^{-3}$. Therefore, in the remaining simulations presented here, we use the aromatic $k_{\mathrm{OH}}$ set with a four-volatility-bin drop per reaction as an upper bound for SOA formation and the alkane $k_{\mathrm{OH}}$ set with the two-volatility-bin drop per reaction as a lower bound for SOA formation. Jimenez et al. (2009) showed that fragmentation would produce more volatile species compared with parent species. The assumption of zero fragmentation and unity SOA mass yield may cause overestimation of SOA production in our study. 


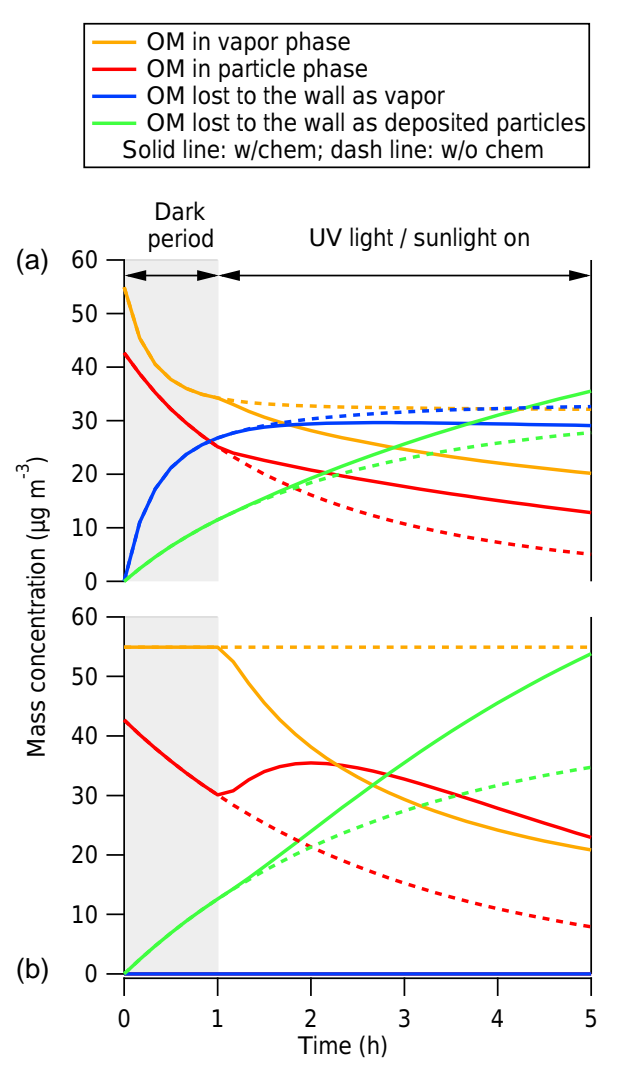

Figure 3. Time evolution of organic mass (OM, in units of $\mu \mathrm{g} \mathrm{m}^{-3}$ ) in the vapor phase (gold lines) and particulate phase (red lines), averaged over the 18 simulations, assuming no chemical reactions occurring (dashed lines) and including oxidation reactions (solid lines). Simulations with chemistry on use $k_{\mathrm{OH}}$ fitted for aromatics with a four-volatility-bin drop in volatility assumed for the products. Model (a) with particle and vapor wall loss on and (b) with vapor wall loss off. Particle-phase wall losses are included in both simulations; the masses of particles and vapors lost to the walls have been normalized by the volume of the bag to obtain mass concentration units. The simulations use Krechmer's saturation concentrations $\left(C_{\mathrm{w}} / M_{\mathrm{w}} \gamma_{\mathrm{w}}\right.$; Krechmer et al., 2016) and a mass accommodation coefficient of $1 \times 10^{-5}$. In all cases, the first hour simulates the process of primary organic aerosol characterization in the dark (no chemical reactions).

\subsection{Influence of particle and vapor wall losses on the apparent SOA production in smog chambers}

Figure 3a shows the time evolution of organic material between the gas, particle, and wall phases, when both particle and vapor wall losses are considered in the model. The first hour simulates the evolution of primary emitted vapor and particulate organics in the dark period prior to initiating photochemistry. OM in the vapor phase decreases as vapor is absorbed into the wall. OM in the particle phase decreases due to both direct particle losses and the loss of aerosol-phase mass from evaporation of the particles driven by the vapor losses to the walls. The extent of the vapor wall loss is mainly controlled by the reversible vapor-wall-loss rate coefficients (i.e., $k_{\text {on }}$ and $k_{\text {off }}$ ) in Eq. 3 . These two variables are mainly influenced by two vapor-wall interaction parameters: the effective saturation concentration of vapor with respect to the wall $\left(C_{\mathrm{w}} / M_{\mathrm{w}} \gamma_{\mathrm{w}}\right)$ and the accommodation coefficient for vapor with the wall, $\alpha_{\mathrm{w}}$ (Bian et al., 2015). We demonstrate the sensitivity of our results to values of these parameters later in this section.

The starting volatility distribution of the chemistry portion of simulations with vapor wall loss on (and base-case assumptions) is shown in Fig. 1b, representing the volatility distribution after $1 \mathrm{~h}$ of vapor-aerosol-wall re-equilibration during the "dark" phase of each smog-chamber experiment (see Bian et al., 2015, for a full analysis of these experiments). Photo-oxidation was then initiated and the simulations were continued for $4 \mathrm{~h}$. The dotted lines in Fig. 3a show how the system evolves over the $5 \mathrm{~h}$ of the experiment when no photo-oxidation is allowed to occur. This evolution is contrasted with that depicted by the solid lines, for which the chemical oxidation mechanism was activated in the model after the first hour (dark/equilibration period), to represent the experimental period when chamber irradiation began; chemistry was allowed to proceed for the next $4 \mathrm{~h}$. In Fig. 3, the upper-bound chemistry assumptions have been applied $\left(k_{\mathrm{OH}}\right.$ set for aromatics with a four-volatility-bin drop per reaction). In Fig. 3a, since particle and vapor wall losses were allowed to continue to occur in parallel with SOA formation from vapor oxidation, the extent of net SOA formation depends on the competition between the oxidation of organic vapors and wall losses of these same vapors, as well as the competition between absorption of product vapors into the walls and into the aerosol phase. The role of the vapors lost to the walls is explored in Fig. 3b, which shows the same case but with vapor wall losses turned off. More SOA is produced in this second case, and OM in the vapor phase is strongly reduced due in part to the higher efficiency of the chemical reactions. In both scenarios, the produced SOA from vapor oxidation compensates some of the OM particle wall loss, but stronger OM production also leads to more OM lost to the wall as deposited particles (green lines). As demonstrated in these examples, the net SOA production in chambers is therefore dependent on interactions between the photochemical reaction rates (and associated changes in organic volatility) and the wall-loss kinetics and applicable parameters (i.e., wall saturation concentration and mass accommodation coefficient of vapors to the wall).

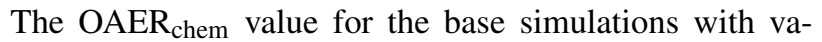
por wall losses on is $2.6 \pm 0.5$ (i.e., the ratio of the solid red to dashed red lines in Fig. 3a, calculated by Eq. 7) af-

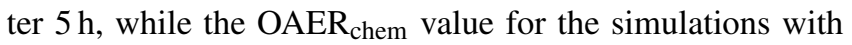
vapor wall losses off (Fig. 3b) is $3.4 \pm 0.7$ at this same time. Thus, these simulations suggest that vapor wall losses measurably reduce the amount of SOA formed in the chamber by removing precursor vapors. In contrast, the averaged OAER $_{\text {inert }}$ value (the metric used by Hennigan et al., 2011, 
to report their experimental observations) for our simulations with vapor wall losses on (Fig. 3a, using BC as the tracer, not shown on this figure) is $1.9 \pm 0.4$ after $5 \mathrm{~h}$, while our $\mathrm{OAER}_{\text {inert }}$ value for the simulations with vapor wall losses off (Fig. 3b) is $3.3 \pm 0.7$. Thus, the OAER inert values are lower than the $\mathrm{OAER}_{\text {chem }}$ values when vapor wall losses are on, but the two metrics are similar when vapor wall losses are off. This difference arises because evaporation of OA, driven by vapor wall losses, decreases the $\mathrm{OA} / \mathrm{BC}$ ratio throughout the experiment, lowering the value of OAER inert $_{\text {. Since }}$ vapor wall losses drive evaporation in both the chem-on and chem-off experiments, $\mathrm{OAER}_{\text {chem }}$ is a better metric for isolating the effect of chemistry than is OAER $\mathrm{Onert}_{\text {. However, }}$ because the differences between OAER inert $_{\text {and }} \mathrm{OAER}_{\mathrm{chem}}$ are not great when vapor wall losses are off, and because $\mathrm{OAER}_{\text {inert }}$ is more directly comparable to the experimental analysis of Hennigan et al. (2011), we use OAER as the representative $\mathrm{OA}$ enhancement ratio for the remainder of the discussion on smog-chamber SOA. We will revisit $\mathrm{OAER}_{\text {chem }}$ when discussing ambient plumes, where $\mathrm{OAER}_{\text {inert }}$ and $\mathrm{OAER}_{\text {chem }}$ show important differences.

Since the initial organic aerosol masses in the simulations are identical to the measurements, we use OAER inert $_{\text {to eval- }}$ uate simulated OA mass against measurements in Figs. 4 and 5 as the inert-tracer wall losses for these experiments have been evaluated in Bian et al. (2015). The range of OAER $_{\text {inert values presented in Hennigan et al. (2011) was }}$ $1.7 \pm 0.7$, so our comparable simulations with vapor wall loss on are in very good agreement with those observations. May et al. (2015) was only able to derive a single volatility distribution across the FLAME III 18 experiments and the IVOC volatility distribution from FLAME IV experiments do not directly correspond to the specific FLAME III experiments. Thus, we expect error in individual simulation-experiment pairs due to the single volatility distributions across all simulations. We thus seek to capture the mean behavior across all of the experiments rather than comparing individual simulations to their corresponding experiments. Our simulations also show that these experimentally derived enhancement ratios would be higher in the absence of vapor wall loss, since our simulated $\mathrm{OAER}_{\text {inert }}$ for the simulations with vapor wall losses off is almost doubled, $3.3 \pm 0.7$. As the predicted underestimation of SOA formation attributed to vapor wall losses depends on our assumptions for various wall-loss parameters and the details of the chemistry scheme, the rest of this section explores how robust these results are to the wall-loss and chemical mechanism uncertainties.

We perform sensitivity tests using documented values of $C_{\mathrm{w}} / M_{\mathrm{w}} \gamma_{\mathrm{w}}\left(9,20,50,120 \mu \mathrm{g} \mathrm{m}^{-3}\right.$ and two sets of $C_{\mathrm{w}} / M_{\mathrm{w}} \gamma_{\mathrm{w}}$ that vary with volatility) to estimate their influence on SOA production in the simulated chamber experiments. $\alpha_{\mathrm{w}}$ is set to $10^{-5}$. Figure 4 a summarizes the predicted values of $\mathrm{OAER}_{\text {inert }}$ under our upper-bound chemistry assumptions ( $k_{\mathrm{OH}}$ set for aromatics with four-volatility-bin drop per reaction) for the various $C_{\mathrm{w}} / M_{\mathrm{w}} \gamma_{\mathrm{w}}$ assumptions, while Fig. $4 \mathrm{~b}$
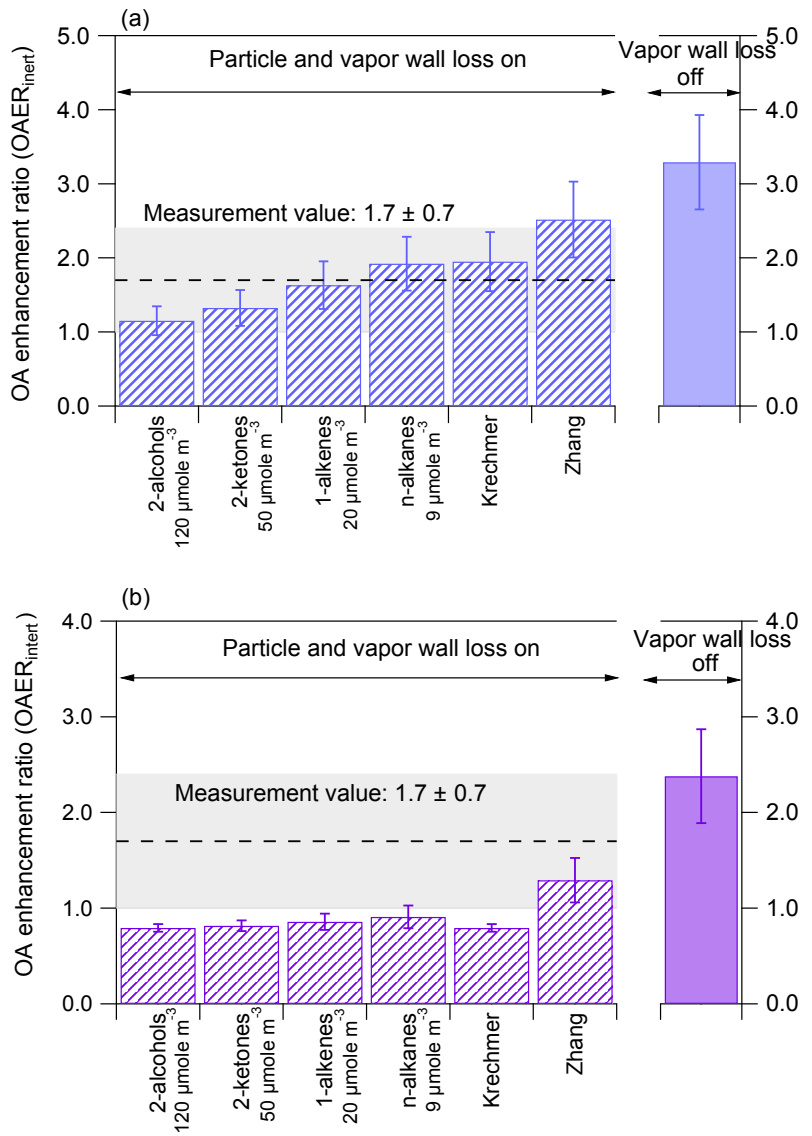

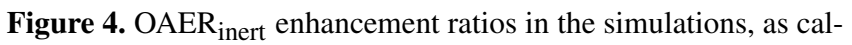
culated from Eq. (7), using saturation concentrations $\left(C_{\mathrm{w}} / M_{\mathrm{w}} \gamma_{\mathrm{w}}\right)$ of $120,50,20$, and $9 \mu$ mole $\mathrm{m}^{-3}$ as suggested by Matsunaga and Ziemann (2010) and for varying $C_{\mathrm{W}} / M_{\mathrm{w}} \gamma_{\mathrm{w}}$ as suggested by Krechmer et al. (2016) and Zhang et al. (2015). Two sets of reaction rates have been applied: (a) upper-bound chemistry $\left(k_{\mathrm{OH}}\right.$ set for aromatics with four-volatility-bin drop per reaction) and (b) lower-bound chemistry $\left(k_{\mathrm{OH}}\right.$ set for alkanes with two-volatility-bin drop per reaction). The mass accommodation coefficient is set to $1 \times 10^{-5}$ in all simulations. The striped bars represent the simulations with particle and vapor wall loss on and the solid bars represent the simulations with vapor wall loss off. The dashed line and grey area represent the measurement value and its standard deviation from Hennigan et al. (2011).

shows the same but for the lower-bound chemistry assumptions $\left(k_{\mathrm{OH}}\right.$ set for alkanes with two-volatility-bin drop per reaction). The OAER $\mathrm{O}_{\text {inert }}$ values using Krechmer's $C_{\mathrm{w}} / M_{\mathrm{w}} \gamma_{\mathrm{w}}$ set are comparable to those using the fixed $9 \mu \mathrm{g} \mathrm{m}^{-3}$ value but less than Zhang's $C_{\mathrm{w}} / M_{\mathrm{w}} \gamma_{\mathrm{w}}$ set, because Krechmer's $C_{\mathrm{w}} / M_{\mathrm{w}} \gamma_{\mathrm{w}}$ leads to more vapor wall losses than Zhang's $C_{\mathrm{w}} / M_{\mathrm{w}} \gamma_{\mathrm{w}}$ (Table 4). The difference in OA enhancement ratios for these varying $C_{\mathrm{w}} / M_{\mathrm{w}} \gamma_{\mathrm{w}}$ is as much as $119 \%$ if estimated using the upper-bound chemistry assumptions (Fig. 4a) and as much as $63 \%$ for the lower-bound assumptions (Fig. 4b). For the upper-bound-chemistry simulations, 
Table 4. Vapor-wall-loss rate constants $\left(\mathrm{s}^{-1}, k_{\mathrm{w}, \mathrm{on}}\right.$, and $\left.k_{\mathrm{W}, \text { off }}\right)$ for each volatility bin for cases with varying $C_{\mathrm{W}} / M_{\mathrm{w}} \gamma_{\mathrm{w}}(\mathrm{Krechmer}$ et al., 2016), for different $\mathrm{XX} \alpha_{\mathrm{w}}$ as shown; last column is for the case varying $C_{\mathrm{W}} / M_{\mathrm{w}} \gamma_{\mathrm{w}}$ as in Zhang et al. (2015).

\begin{tabular}{|c|c|c|c|c|c|c|c|c|}
\hline \multirow[b]{2}{*}{$\log _{10} C^{*}$} & \multicolumn{2}{|c|}{$\begin{array}{c}\text { Varying } C_{\mathrm{w}} / M_{\mathrm{w}} \gamma_{\mathrm{w}} \\
\text { (Krechmer et al., 2016); } \\
\quad \alpha_{\mathrm{w}}=1 \times 10^{-5}\end{array}$} & \multicolumn{2}{|c|}{$\begin{array}{c}\text { Varying } C_{\mathrm{W}} / M_{\mathrm{w}} \gamma_{\mathrm{w}} \\
\text { (Krechmer et al., 2016); } \\
\alpha_{\mathrm{W}}=1\end{array}$} & \multicolumn{2}{|c|}{$\begin{array}{c}\text { Varying } C_{\mathrm{W}} / M_{\mathrm{w}} \gamma_{\mathrm{w}} \\
\text { (Krechmer et al., 2016); } \\
\text { varying } \alpha_{\mathrm{w}} \\
\text { (Zhang et al., 2015) }\end{array}$} & \multicolumn{2}{|c|}{$\begin{array}{l}\text { Varying } C_{\mathrm{W}} / M_{\mathrm{w}} \gamma_{\mathrm{w}} \\
\text { (Zhang et al., } 2015 \text { ); } \\
\quad \alpha_{\mathrm{W}}=1 \times 10^{-5}\end{array}$} \\
\hline & $k_{\mathrm{on}}$ & $k_{\text {off }}$ & $k_{\text {on }}$ & $k_{\mathrm{off}}$ & $k_{\text {on }}$ & $k_{\text {off }}$ & $k_{\mathrm{On}}$ & $k_{\text {off }}$ \\
\hline-3 & $7.33 \times 10^{-4}$ & $2.01 \times 10^{-8}$ & $4.01 \times 10^{-3}$ & $1.10 \times 10^{-7}$ & $1.55 \times 10^{-4}$ & $4.26 \times 10^{-9}$ & $7.33 \times 10^{-4}$ & $9.90 \times 10^{-5}$ \\
\hline-2 & $7.58 \times 10^{-4}$ & & $4.02 \times 10^{-3}$ & & $1.05 \times 10^{-4}$ & & $7.58 \times 10^{-4}$ & \\
\hline-1 & $7.86 \times 10^{-4}$ & $2.56 \times 10^{-6}$ & $4.02 \times 10^{-3}$ & $1.31 \times 10^{-5}$ & $7.15 \times 10^{-5}$ & $2.33 \times 10^{-7}$ & $7.86 \times 10^{-4}$ & $2.55 \times 10^{-4}$ \\
\hline 0 & $8.18 \times 10^{-4}$ & $2.94 \times 10^{-5}$ & $4.03 \times 10^{-3}$ & $1.45 \times 10^{-4}$ & $4.86 \times 10^{-5}$ & $1.75 \times 10^{-6}$ & $8.18 \times 10^{-4}$ & $4.16 \times 10^{-4}$ \\
\hline 1 & $8.54 \times 10^{-4}$ & $8.61 \times 10^{-5}$ & $4.03 \times 10^{-3}$ & & $3.31 \times 10^{-5}$ & $3.34 \times 10^{-6}$ & $8.54 \times 10^{-4}$ & $6.91 \times 10^{-4}$ \\
\hline 2 & $8.97 \times 10^{-4}$ & $2.57 \times 10^{-4}$ & $4.04 \times 10^{-3}$ & $1.16 \times 10^{-3}$ & $2.27 \times 10^{-5}$ & $6.51 \times 10^{-6}$ & $8.97 \times 10^{-4}$ & $1.16 \times 10^{-3}$ \\
\hline 3 & $9.47 \times 10^{-4}$ & & $4.06 \times 10^{-3}$ & $3.36 \times 10^{-3}$ & $1.56 \times 10^{-5}$ & $1.30 \times 10^{-5}$ & $9.47 \times 10^{-4}$ & $2.02 \times 10^{-3}$ \\
\hline 4 & $1.01 \times 10^{-3}$ & $2.47 \times 10^{-3}$ & $4.07 \times 10^{-3}$ & $9.97 \times 10^{-3}$ & $1.09 \times 10^{-5}$ & $2.68 \times 10^{-5}$ & $1.01 \times 10^{-3}$ & $3.58 \times 10^{-3}$ \\
\hline 5 & $1.09 \times 10^{-3}$ & $6.50 \times 10^{-3}$ & $4.09 \times 10^{-3}$ & $2.45 \times 10^{-2}$ & $7.75 \times 10^{-6}$ & $4.63 \times 10^{-5}$ & $1.09 \times 10^{-3}$ & $6.68 \times 10^{-3}$ \\
\hline 6 & $1.10 \times 10^{-3}$ & & $4.10 \times 10^{-3}$ & $2.56 \times 10^{-1}$ & $5.10 \times 10^{-6}$ & $3.19 \times 10^{-4}$ & $1.10 \times 10^{-3}$ & $1.01 \times 10^{-2}$ \\
\hline 7 & $1.10 \times 10^{-3}$ & $6.90 \times 10^{-1}$ & $4.10 \times 10^{-3}$ & $2.56 \times 10^{0}$ & $3.28 \times 10^{-6}$ & $2.05 \times 10^{-3}$ & $1.10 \times 10^{-3}$ & $1.43 \times 10^{-2}$ \\
\hline 8 & $1.10 \times 10^{-3}$ & $6.90 \times 10^{0}$ & $4.10 \times 10^{-3}$ & $2.56 \times 10^{1}$ & $2.12 \times 10^{-6}$ & $1.32 \times 10^{-2}$ & $1.10 \times 10^{-3}$ & $2.05 \times 10^{-2}$ \\
\hline 9 & $1.10 \times 10^{-3}$ & $6.90 \times 10^{1}$ & $4.10 \times 10^{-3}$ & $2.56 \times 10^{2}$ & $1.36 \times 10^{-6}$ & $8.47 \times 10^{-2}$ & $1.10 \times 10^{-3}$ & $2.91 \times 10^{-2}$ \\
\hline 10 & $1.10 \times 10^{-3}$ & $6.90 \times 10^{2}$ & $4.10 \times 10^{-3}$ & $2.56 \times 10^{3}$ & $8.72 \times 10^{-7}$ & $5.45 \times 10^{-1}$ & $1.10 \times 10^{-3}$ & $4.12 \times 10^{-2}$ \\
\hline 11 & $1.10 \times 10^{-3}$ & $6.90 \times 10^{3}$ & $4.10 \times 10^{-3}$ & $2.56 \times 10^{4}$ & $5.61 \times 10^{-7}$ & $3.50 \times 10^{0}$ & $1.10 \times 10^{-3}$ & $5.87 \times 10^{-2}$ \\
\hline
\end{tabular}

$\mathrm{OAER}_{\text {inert }}$ for the simulations using $C_{\mathrm{w}} / M_{\mathrm{w}} \gamma_{\mathrm{w}}$ of 20 and $9 \mu$ mole $\mathrm{m}^{-3}$ and Krechmer's values $(1.6,1.9$, and 1.9) are close to the experimental values $(1.7 \pm 0.7)$ reported by Hennigan et al. (2011), suggesting our simulations using these parameter settings could reflect the conditions in the chamber experiments. Generally, the lower-bound-chemistry simulations all underpredict the experimental range of Hennigan et al. (2011). Most of those simulations result in a net loss

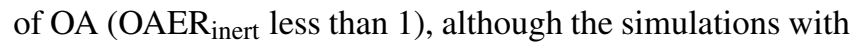
the Zhang $C_{\mathrm{w}} / M_{\mathrm{w}} \gamma_{\mathrm{w}}$ set overlap with the low end of the Hennigan et al. (2011) range.

The vapor accommodation coefficient with the walls, $\alpha_{\mathrm{w}}$, has also been demonstrated to be an important parameter in chambers that influences the vapor-wall-loss rates (Zhang et al., 2014; Bian et al., 2015). A value of 1 represents no limitation on the vapor-wall-loss rates due to this process. Based on their series of lab studies, Matsunaga and Ziemann (2010) recommended values of $\alpha_{\mathrm{w}}$ larger than $10^{-5}$. Zhang et al. (2014) and Bian et al. (2015) both showed the insensitivity of vapor wall loss to $\alpha_{\mathrm{w}}$ when $\alpha_{\mathrm{w}}>10^{-4}$, but vapor wall loss was largely suppressed using the varying $\alpha_{\mathrm{w}}$ as a function of $C^{*}$ that was suggested by Zhang et al. (2015). We thus simulate the experiments for choices of $\alpha_{\mathrm{w}}=1$ and for varying $\alpha_{\mathrm{w}}$ as sensitivity tests from our previously assumed value of $10^{-5} . C_{\mathrm{w}} / M_{\mathrm{w}} \gamma_{\mathrm{w}}$ is set to Krechmer's values for this series of simulations. Figure 5 shows that assuming $\alpha_{\mathrm{w}}=1$ decreases OAER inert $_{\text {by }} 18-31 \%$ compared with the base-case simulations using $\alpha_{\mathrm{w}}=1 \times 10^{-5}$, since $k_{\text {on }}$ is nearly 1 order of magnitude higher for $\alpha_{\mathrm{w}}=1$ than

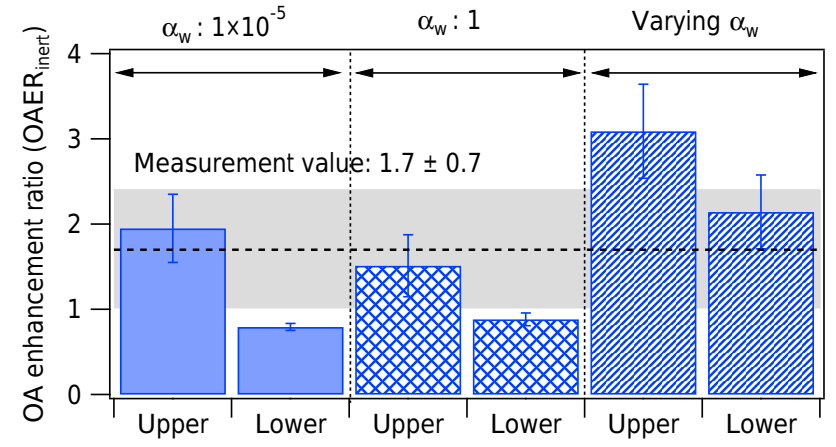

Figure 5. The effect of variable mass accommodation coefficients

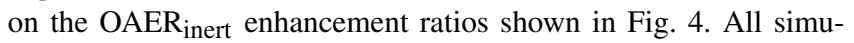
lations used varying $C_{\mathrm{w}} / M_{\mathrm{w}} \gamma_{\mathrm{w}}$ (Krechmer et al., 2016). Results for upper- and lower-bound chemistry assumptions are shown, with assumed $\alpha_{\mathrm{W}}$ of $1 \times 10^{-5}$ (solid bars), 1 (gridded bars), and varying $\alpha_{\mathrm{w}}$ as a function of $C^{*}$ (striped bars; Zhang et al., 2015). The dashed line and grey area represent the measurement value and its standard deviation from Hennigan et al. (2011).

for $\alpha_{\mathrm{w}}=1 \times 10^{-5}$ (Table 3 ). In contrast, OAER inert nearly doubles when using the varying $\alpha_{\mathrm{w}}$ relative to the $1 \times 10^{-5}$ simulations, as vapor wall loss is slower on average for the varying $\alpha_{\mathrm{w}}$ (i.e., $3.7 \times 10^{-9}$ to $1.1 \times 10^{-6}$ for our simulated $C^{*}$ range). Compared with the experimental values of Hennigan et al. (2011), it appears that using $\alpha_{\mathrm{w}}$ of $1 \times 10^{-5}$, or the varying $\alpha_{\mathrm{w}}$ values with the lower-bound-chemistry assumptions, can better represent the FLAME III experiments; 

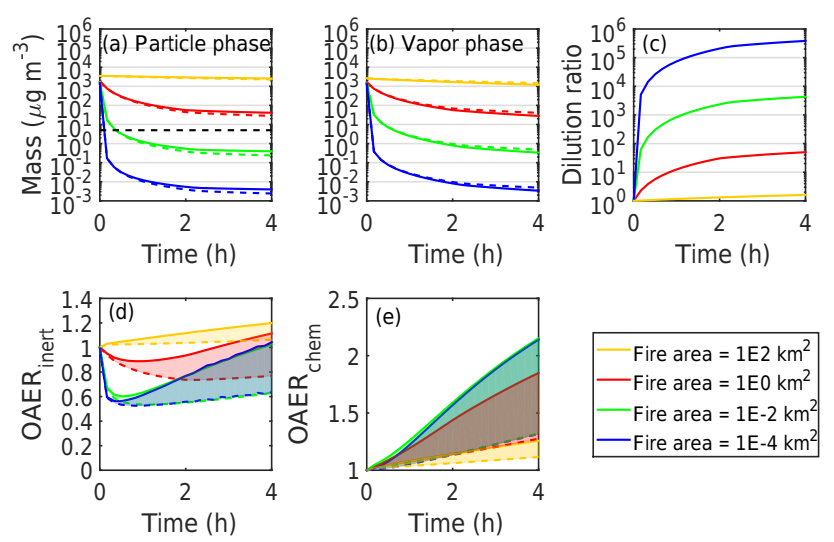

Figure 6. Time evolution of (a) organic mass (OM) in the particle phase, (b) $\mathrm{OM}$ in the vapor phases, (c) dilution ra-

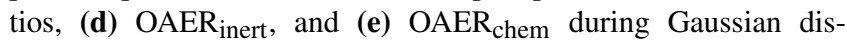
persion, using the parameters listed in Table 3 with fire areas of $100,1,1 \times 10^{-2}$ and $1 \times 10^{-4} \mathrm{~km}^{2}$ and an emission flux of $5 \times 10^{-6} \mathrm{~kg} \mathrm{~m}^{-2} \mathrm{~s}^{-1}$. Solid lines represent the upper-boundchemistry simulations and dashed lines represent the lower-boundchemistry simulations. Shaded areas bound the ranges of estimated OA enhancement. The black dashed line on panel a represents the background nonvolatile OA concentration $\left(5 \mu \mathrm{g} \mathrm{m}^{-3}\right)$.

however, we are unable to provide the "best-fit parameters" for the simulations as we cannot determine which set of $\alpha_{\mathrm{w}}, C_{\mathrm{w}} / M_{\mathrm{w}} \gamma_{\mathrm{w}}$, and chemistry assumptions best represent the actual processes occurring in the chamber, since different combinations of these values can reproduce the observed OAER $_{\text {inert }}$ range.

Whether the upper- or lower-bound chemical mechanism assumptions are applied, our simulations show that $\mathrm{OAER}_{\text {inert }}$ increases significantly for most of the cases when vapor wall losses are shut off, implying that vapor-wallloss suppression of SOA formation is a robust result across our simulations (Fig. 4). For example, OAER inert $_{\text {for the }}$ upper-bound-chemistry simulations without vapor wall loss is $3.3 \pm 0.7$ (Fig. $4 \mathrm{a}$ ), or over a $200 \%$ increase in OA attributable to chemical formation of SOA from species that are lost to the walls in typical experiments. Most of the measurements and simulations including vapor wall losses result in OA increases due to SOA formation of $100 \%$ or less. Thus, our simulations imply that SOA production in biomass-burning-smoke SOA laboratory smog-chamber experiments may be underestimated by a factor of 2 or more due to vapor wall losses and that applying lab-derived apparent SOA formation rates to simulations of the evolution of ambient OA would similarly underestimate the impacts of photo-oxidation of biomass-burning products. We explore these potential atmospheric impacts in the next section.
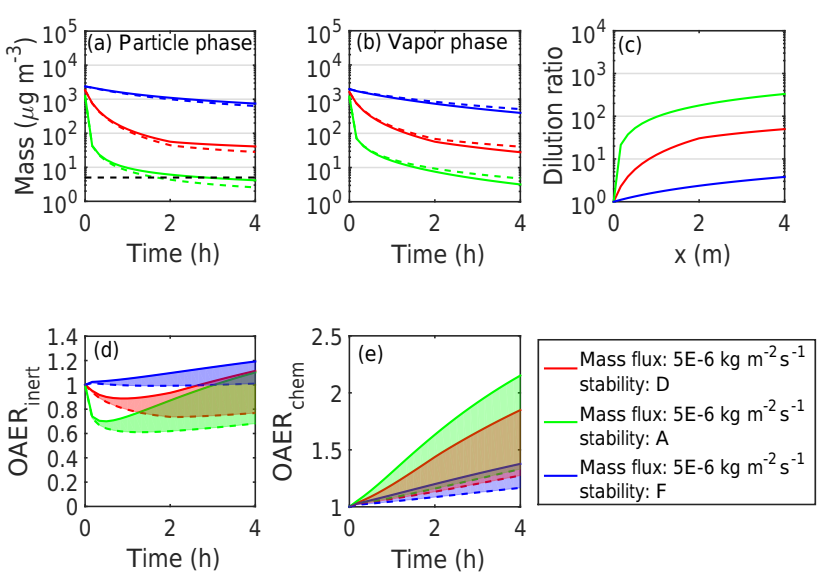

Figure 7. Time evolution during Gaussian dispersion of (a) organic mass $(\mathrm{OM})$ in the particle phase, (b) OM in the vapor phases, (c) dilution ratio, (d) $\mathrm{OAER}_{\text {inert }}$, and (e) $\mathrm{OAER}_{\text {chem }}$, with a fire area of $1 \mathrm{~km}^{2}$, a mass flux (ML) of $5 \times 10^{-6} \mathrm{~kg} \mathrm{~m}^{-2} \mathrm{~s}^{-1}$, and assuming different atmospheric stability classes (A, D, and F; see Table 3). The black dashed line on panel a represents the background nonvolatile OA concentration $\left(5 \mu \mathrm{g} \mathrm{m}^{-3}\right)$.

\subsection{SOA production in ambient plumes}

The semivolatile nature of organics from biomass burning not only complicates SOA estimation from chamber studies but can also influence OA evolution during plume transport and dilution. In dispersion, the initial plume cross-sectional area is a key factor that determines the relative plume dilution rate during transport (Sakamoto et al., 2016). The initial plume width is associated with fire size, which means that the fire size could largely influence the plume evolution (Sakamoto et al., 2016). Cochrane et al. (2012) reported 14 wildfires with fire size from 5 to over $1000 \mathrm{~km}^{2}$. Akagi et al. (2013) also recorded the burn areas for the observed prescribed fire range from 0.162 to $1.47 \mathrm{~km}^{2}$. The burning area for Williams fire was $0.81 \mathrm{~km}^{2}$ (Akagi et al., 2012). The fire size for agricultural and pile burns can be as small as $7 \times 10^{-5} \mathrm{~km}^{2}$ (Springsteen et al., 2015). We therefore perform simulations on the evolution of ambient OA concentrations over $4 \mathrm{~h}$ of simulated transport, for four different fire areas of $1 \times 10^{-4}, 1 \times 10^{-2}, 1 \times 10^{0}$, and $1 \times 10^{2} \mathrm{~km}^{2}$ (with the fire width assumed to be the square root of these areas), which largely cover the reported burned areas above. In these simulations, we set the mass flux to $5 \times 10^{-6} \mathrm{~kg} \mathrm{~m}^{-2} \mathrm{~s}^{-1}$ and the atmospheric stability to the neutral atmospheric Pasquill stability condition, $D$. The initial mass concentrations for different-sized fires are assumed to be similar in all cases $\left(\sim 10^{3} \mu \mathrm{g} \mathrm{m}^{-3}\right)$. The simulated time evolution of various key quantities is shown for each of the four different fire sizes in Fig. 6, with the upper-bound chemistry cases shown as solid lines and the lower-bound chemistry as dotted lines.

The OM concentration in the gas and particle phases predicted for the small fire $\left(1 \times 10^{-4} \mathrm{~km}^{2}\right.$, prescribed fire size $)$ 

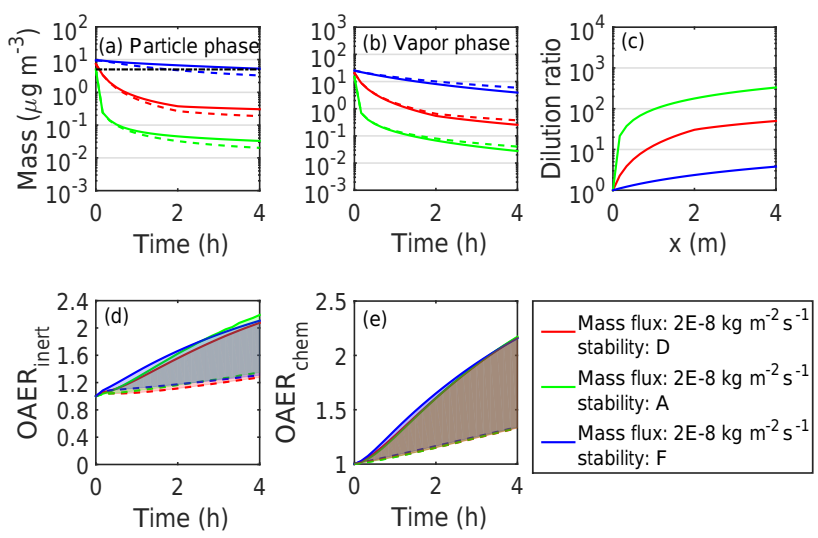

Figure 8. As in Fig. 7 but for an assumed mass flux of $2 \times 10^{-8} \mathrm{~kg} \mathrm{~m}^{-2} \mathrm{~s}^{-1}$.

drops quickly from $1 \times 10^{3}$ to $3 \times 10^{-3} \mu \mathrm{g} \mathrm{m}^{-3}$ over the 4 simulated hours (blue lines, Fig. 6a and b) due to the strong dilution: a dilution ratio of over $10^{5}$ with respect to the initial volume is achieved within $2 \mathrm{~h}$, as shown in Fig. $6 \mathrm{c}$. The OA concentration for the large fire $\left(1 \times 10^{2} \mathrm{~km}^{2}\right.$, wildfire size $)$ decreases from around $3 \times 10^{3}$ to $1 \times 10^{3} \mathrm{\mu g} \mathrm{m}^{-3}$ because of weak dilution (dilution ratio $<10$ ). OAER $_{\text {inert }}$ increases to around 1.06-1.20 (depending on upper- versus lower-bound chemistry) for the $100 \mathrm{~km}^{2}$ fire area; however, for the smaller fires, $\mathrm{OAER}_{\text {inert }}$ initially decreases due to the dominant role of OA evaporation driven by dilution but eventually recovers as SOA formation rates exceed the loss rates (particularly for the upper-bound-chemistry simulations; Fig. 6d). The upper-bound-chemistry simulated OAER inert $_{\text {after }} 4 \mathrm{~h}$ transport is above 1 , while OAER inert $_{\text {remains below } 1 \text { for the }}$ small fires in the lower-bound-chemistry simulations. Thus, the range in the simulations shown in Fig. 6d captures the range in the competition between OA evaporation due to dilution and OA formation due to chemistry and condensation. Interestingly, $\mathrm{OAER}_{\text {inert }}$ evolves virtually identically for the two smallest fires (Fig. 6d) despite different dilution ratios (Fig. 6c) due to the biomass-burning OA concentrations dropping below the concentration background OA entrained into the plume $\left(5 \mu \mathrm{g} \mathrm{m}^{-3}\right)$ in both plumes, which suggests that the background OA concentration also plays a role affecting the OAER values.

Atmospheric stability is an important parameter that influences the dilution rate. Figures 7 and 8 show the impacts on the predictions of changing atmospheric stability for low (Fig. 7) and high (Fig. 8) emission mass fluxes $\left(2 \times 10^{-8}\right.$ and $5 \times 10^{-6} \mathrm{~kg} \mathrm{~m}^{-2} \mathrm{~s}^{-1}$ ), all for moderate $1 \mathrm{~km}^{2}$ fire areas. Unstable atmospheres (stability class A) favor the vertical and horizontal mixing of air parcels that enhances dilution (Fig. 7c). Stable atmospheres (stability class F) resist vertical mixing and have weaker dilution. Therefore, OA evolution in unstable atmospheres (A) behaves qualitatively similar to the small fires in Fig. 7 and has a similar decreasing-then-increasing pattern for OAER inert $_{\text {. OA evolu- }}$ tion in stable atmospheres $(\mathrm{F})$ behaves qualitatively similar to the large fires in Fig. 7, leading to a steady increase in OAER $_{\text {inert }}$ with time (Fig. 7). For the low-emission mass flux

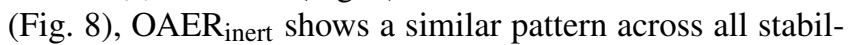
ity classes, increasing steadily with time. This monotonic increase arises because the plumes begin in a dilute state where the biomass-burning OA concentrations quickly drop below the background nonvolatile OA concentrations entrained into the plume $\left(5 \mu \mathrm{g} \mathrm{m}^{-3}\right)$. In this limit, further dilution does not lead to further evaporation, so in each of the stability cases chemistry exceeds evaporation. Again, this shows that the results should be sensitive to background nonvolatile OA concentrations. Fire intensity also influences OA evolution in the plume through changes in emission fluxes. Compared OA evolution for fire size of $1 \mathrm{~km}^{2}$ under Atmospheric Class of D in Figs. 7 and 8, high emission mass flux (i.e., large fire intensity) has lower OAER inert $_{\text {and }} \mathrm{OAER}_{\text {chem }}$ than that of low emission mass flux, suggesting that under the same dilution ratio, lower emission mass flux has slightly more effective SOA formation. OA concentrations for lower emission mass flux quickly drop close or below the background nonvolatile OA concentrations and further dilution does not lead to further evaporation. The evaporated organics are available for SOA formation. Both of OAER inert $_{\text {and }} \mathrm{OAER}_{\text {chem }}$ after $4 \mathrm{~h}$ were thus higher for low emission mass flux than high emission mass flux.

The sensitivity tests shown in Figs. 6-8 demonstrate that $\mathrm{OA}$ enhancement ratios measured in the field using $\mathrm{BC}$ or $\mathrm{CO}$ as a conserved tracer $\left(\mathrm{OAER}_{\text {inert }}\right)$ may undergo very different trajectories based on (1) the fire size, (2) the emissions mass flux, and (3) the stability of the atmosphere - even when the OA volatility distribution and chemical mechanisms are identical. This variance with fire size, mass flux, and stability may explain at least some of the variability in the measured time evolution of OA enhancement ratios $\left(\mathrm{OAER}_{\text {inert }}\right)$ reported in field studies. For nighttime OA evolution, it may be difficult to generalize about day-night differences due to various aspects being different between day and night on average. In general, nighttime plumes may have (1) less dispersion in the boundary layer due to more stable air, (2) different chemistry, and (3) lower emission fluxes as peak fire intensities are typical during the day (this may affect fire size too; Zhang and Kondragunta, 2008; Robert et al., 2009). It is unclear how the convolution of these differences might impact the plumes, and it probably varies between cases.

\subsection{Is the traditional OA enhancement ratio reported in field studies a good proxy for SOA formation? OAER $_{\text {inert }}$ versus $O A E R_{\text {chem }}$}

As described earlier, $\mathrm{OAER}_{\text {inert }}$ (the $\mathrm{OA}$ enhancement ratio calculated by using an inert tracer, such as $\mathrm{BC}$, to account for physical dilution) and $\mathrm{OAER}_{\text {chem }}$ (the OA enhancement ratio calculated comparing simulations with chemistry on versus 
chemistry off) differed for our simulations of smog-chamber experiments with vapor wall losses on. We find that the differences between OAER ${ }_{\text {chem }}$ and $\mathrm{OAER}_{\text {inert }}$ can be even more dramatic in our plume simulations. Figure 6 shows that OAER $_{\text {chem }}$ increases steadily across all four different-sized fires. Unlike OAER inert, which had the largest increases for the large fire, $\mathrm{OAER}_{\text {chem }}$ has the largest increases for small fires, reaching values of 2.2 for the small fires and 1.3 for the large fires (with upper-bound chemistry). More organic material is evaporated from particles in plumes of smaller fires, which gives a larger reservoir of SOA precursors to generate SOA, compared to the plumes of larger fires. Thus, while $\mathrm{OAER}_{\text {inert }}$ estimates that are traditionally reported in field studies may show values similar to or less than 1 , the OA in these plumes may actually be strongly enhanced by SOA formation, and indeed evaporation of precursors driven by dilution is required to replenish the reservoir of SOA precursors in the gas phase so that these processes are not only in competition but are dependent on each other. In cases where little apparent SOA production is occurring, our studies suggest that SOA formation is simply balancing the loss of OA from evaporation. Papers analyzing field observations have suggested this possibility. Capes et al. (2008) and Cubison et al. (2011) observed significant increases in $\mathrm{O}: \mathrm{C}$ ratios of the organic aerosol, as well as a small decrease in the normalized OA mass concentrations. Akagi et al. (2012) observed the decrease of OA and attributed this to the processes of particle evaporation. Similarly, Jolleys et al. (2015) observed the increased $\mathrm{O}: \mathrm{C}$ elemental ratio but lower OA in the smoke plumes, and they attributed this to the combination of dilution and chemical processing. May et al. (2015) also suggested the competition between dilution-driven evaporation and SOA formation during the plume transport may be occurring in their observed plumes, as they found approximately $50 \%$ reduction of OA after several hours of aging with increasing in the $\mathrm{O}: \mathrm{C}$ ratio. Additionally, the lab study of Hennigan et al. (2011) also showed increased $\mathrm{O}: \mathrm{C}$ ratios in experiments with decreasing OA concentrations. Our modeling result is consistent with the findings from these observational studies reporting increased oxygenation with time for the OA even with observed decreases in the relative amount of OA (or a relative constant or lower OAER $_{\text {inert }}$ ).

Analogous results are shown for the influence of atmo-

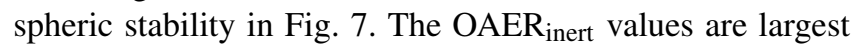
for the most-stable conditions. In contrast, $\mathrm{OAER}_{\mathrm{chem}}$ values are largest for the least stable conditions that have the most organic-vapor evaporation generating the largest pool of SOA-precursor vapors. Under low-emission-flux conditions (Fig. 8), the plume is already dilute upon emission and thus both OAER $_{\text {inert }}$ and $\mathrm{OAER}_{\text {chem }}$ have nearly identical values, monotonically increasing with transport time.

This comparison of OAER inert $_{\text {and }} \mathrm{OAER}_{\text {chem }}$ shows that $\mathrm{OAER}_{\text {inert }}$ computed from field measurements may not be indicative of the relative amount of SOA formed in the plume due to competition with OA loss to dilution. Further, the relationship between $\mathrm{OAER}_{\text {inert }}$ and $\mathrm{OAER}_{\text {chem }}$ can depend greatly on the fire size, smoke emission flux, and the atmospheric stability, and different conclusions regarding the efficiency and impact of photooxidation can be drawn for the same fuels, combustion phases, and chemical mechanisms if the emissions are sampled under those varying fire size and environmental conditions.

\section{Summary and conclusions}

We investigated some processes controlling biomassburning OA evolution in smog chambers and in ambient plumes. We used aerosol-microphysical simulations with resolved organic volatility, kinetic condensation/evaporation, and gas-phase chemistry (ignoring potential particle- and heterogeneous-phase chemistry) to explore these processes. We found that differences seen between laboratory and field observations may be explained, in part, due to processes that control OA evaporation (and SOA-precursor losses) in these experiments.

For laboratory smog-chamber experiments in Teflon chambers (specifically the FLAME III experiments reported by Hennigan et al., 2011), our simulations showed that vapor wall losses remove SOA-precursor vapors and drive OA evaporation. Uncertainties in parameters that control vapor wall losses, such as the wall saturation concentration and wall accommodation coefficient, as well as uncertainties in gas-phase chemistry with the assumption of zero fragmentation and unity SOA mass yield, lead to uncertainties in our simulations. We are able to reproduce the observed OA concentration profiles from the FLAME III experiments using a range of wall-loss and chemistry parameters that fall within previously published estimates, but there is no unique set of parameters that can be identified at this time. However, under all assumed parameters, the apparent SOA formation was suppressed by vapor wall losses. For the simulations that best reproduced the OA concentration profiles from the FLAME III experiments, we found that turning off vapor wall losses in these simulations leads to $2-3 \times$ increases in the total apparent SOA production in the experiment. Thus, vapor-phase wall losses should be considered and corrected for in biomass-burning SOA smog-chamber experiments.

For ambient expanding plumes, we showed through similar simulations with identical gas-phase chemistry assumptions that the fire area, mass emissions flux, and atmospheric stability strongly modulate initial plume concentrations and plume dilution rates. Conditions with fast dilution (small fire areas and unstable atmospheric conditions) drive faster $\mathrm{OA}$ evaporation relative to slow-dilution conditions. However, the evaporated OA serves as precursor vapors for SOA formation. Thus, quickly diluting plumes may have substantial initial drops in the ratio of OA to inert tracers (relative to slowly diluting plumes), but the ratio of OA to inert tracers 
later increases more rapidly in the quickly diluting plumes due to the faster SOA formation.

To decouple the influences of POA evaporation and SOA formation on the evolution of the net OA, we defined two

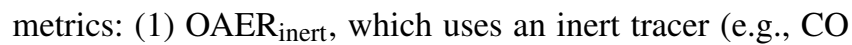
or $\mathrm{BC}$ ) to normalize $\mathrm{OA}$ in the plume as is commonly done in laboratory and field experiments, and (2) OAER ${ }_{\text {chem }}$, which uses a simulation with chemistry turned off to normalize the OA in the plume, which is generally only possible in mod-

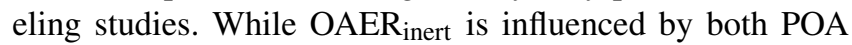
evaporation and SOA condensation, $\mathrm{OAER}_{\text {chem }}$ shows influence of SOA condensation which allowed us to decouple the influence of POA evaporation and SOA condensation. Through these two metrics, we showed that many plumes with $\mathrm{OAER}_{\text {inert }}$ values near 1 (implying little net change in OA) may be strongly influenced by SOA production that is balanced by POA evaporation. We found the SOA-production influence to be strongest for rapidly diluting plumes (such as those from small-area fires or under unstable atmospheric conditions), where SOA may contribute to a doubling of OA concentrations within $4 \mathrm{~h}$ relative to a simulation with chemistry off, even though field measurements might have observed little to no net change in OA in the plume with time.

Our results highlight that the evolution of $\mathrm{OA}$ in the atmosphere depends on more than the details of the fuel types, the combustion efficiency of those fuels. The size of the fire and the meteorological conditions may also influence whether a net OA increase or decrease is inferred, when OA is normalized with an inert tracer. The large range in reported observed OA changes in experiments and ambient-plume profiles (e.g., Grieshop et al., 2009; Yokelson et al., 2009; Cubison et al., 2011; Hennigan et al., 2011; Akagi et al., 2012; Ortega et al., 2013; May et al., 2015) may be explained, in part, by these factors. Additionally, as we used identical chemistry assumptions in all of our simulations, we showed that the changes in OA with time in laboratory and field experiments cannot easily be compared to each other due to different influences of chamber walls and plume dilution. The apparent observed OA evolution in the laboratory and field may be drastically different (e.g., showing a net gain in the lab while showing a net loss in the field) even with identical chemical mechanisms and rates in the laboratory and field experiments. These findings may also explain in part the systematic inconsistencies in reported OA enhancements measured in the laboratory and in field experiments (e.g., Jolleys et al., 2014). Thus, laboratory and field observations require a thorough understanding of the processes that drive OA evaporation (and SOA-precursor losses) before the impact of photochemical SOA production can be isolated and quantified.

Data availability. Data are available at US Forest Service Research Data Archive (https://www.fs.usda.gov/rds/archive/; Bian et al., 2017).
Competing interests. The authors declare that they have no conflict of interest.

Acknowledgements. This study was supported by the Joint Fire Science Program (JFSP) under projects of 14-1-03-26 and 14-103-44. We thank the Fire Lab At Missoula Experiment (FLAME) III project team and Cyle Wold, Emily Lincoln, and Wei Min Hao from the FSL for their support in organizing and conducting the FLAME III study and for providing the data set used here. We thank Chris Hennigan, Gabriella Engelhart, Marissa Miracolo, Albert Presto, and Allen Robinson for their smog-chamber measurements during FLAME III. Funding for the FLAME III project was provided by the National Park Service, JFSP, and the EPA STAR program through the National Center for Environmental Research (NCER) under grants R833747 and R834554 and DOE (BER, ASR program) DE-SC0006035. The views, opinions, and/or findings contained in this paper are those of the authors and should not be construed as an official position of the funding agencies. Although the research described in this article has been funded in part by the United States Environmental Protection Agency, it has not been subjected to the agency's required peer and policy review and therefore does not necessarily reflect the views of the agency and no official endorsement should be inferred.

Edited by: D. Topping

Reviewed by: two anonymous referees

\section{References}

Abramowitz, M. and Stegun, I.: Handbook of Mathematical Functions: With Formulas, Graphs, and Mathematical Tables, Courier Corporation, Dover, New York, 1964.

Adams, P. J. and Seinfeld, J. H.: Predicting global aerosol size distributions in general circulation models, J. Geophys. Res., 107, 4370, doi:10.1029/2001JD001010, 2002.

Akagi, S. K., Yokelson, R. J., Wiedinmyer, C., Alvarado, M. J., Reid, J. S., Karl, T., Crounse, J. D., and Wennberg, P. O.: Emission factors for open and domestic biomass burning for use in atmospheric models, Atmos. Chem. Phys., 11, 4039-4072, doi:10.5194/acp-11-4039-2011, 2011.

Akagi, S. K., Craven, J. S., Taylor, J. W., McMeeking, G. R., Yokelson, R. J., Burling, I. R., Urbanski, S. P., Wold, C. E., Seinfeld, J. H., Coe, H., Alvarado, M. J., and Weise, D. R.: Evolution of trace gases and particles emitted by a chaparral fire in California, Atmos. Chem. Phys., 12, 1397-1421, doi:10.5194/acp-12-13972012, 2012.

Akagi, S. K., Yokelson, R. J., Burling, I. R., Meinardi, S., Simpson, I., Blake, D. R., McMeeking, G. R., Sullivan, A., Lee, T., Kreidenweis, S., Urbanski, S., Reardon, J., Griffith, D. W. T., Johnson, T. J., and Weise, D. R.: Measurements of reactive trace gases and variable $\mathrm{O}_{3}$ formation rates in some South Carolina biomass burning plumes, Atmos. Chem. Phys., 13, 1141-1165, doi:10.5194/acp-13-1141-2013, 2013.

Alvarado, M. J. and Prinn, R. G.: Formation of ozone and growth of aerosol in young smoke plumes from biomass burning: 1 . Lagrangian parcel studies, J. Geophys. Res., 114, D09306, doi:10.1029/2008JD011144, 2009. 
Alvarado, M. J., Lonsdale, C. R., Yokelson, R. J., Akagi, S. K., Coe, H., Craven, J. S., Fischer, E. V., McMeeking, G. R., Seinfeld, J. H., Soni, T., Taylor, J. W., Weise, D. R., and Wold, C. E.: Investigating the links between ozone and organic aerosol chemistry in a biomass burning plume from a prescribed fire in California chaparral, Atmos. Chem. Phys., 15, 6667-6688, doi:10.5194/acp15-6667-2015, 2015.

Atkinson, R. and Arey, J.: Atmospheric Degradation of Volatile Organic Compounds, Chem. Rev., 103, 4605-4638, doi:10.1021/cr0206420, 2003.

Bian, Q., May, A. A., Kreidenweis, S. M., and Pierce, J. R.: Investigation of particle and vapor wall-loss effects on controlled wood-smoke smog-chamber experiments, Atmos. Chem. Phys., 15, 11027-11045, doi:10.5194/acp-15-11027-2015, 2015.

Bian, Q., Kreidenweis, S. M., and Pierce, J. R.: Phase dynamics of wildland fire smoke emissions and their secondary organic aerosols, available at: https://www.fs.usda.gov/ rds/archive/, doi:10.2737/RDS-2017-0019, under review, 2017.

Bond, T. C., Doherty, S. J., Fahey, D. W., Forster, P. M., Berntsen, T., DeAngelo, B. J., Flanner, M. G., Ghan, S., Kärcher, B., Koch, D., Kinne, S., Kondo, Y., Quinn, P. K., Sarofim, M. C., Schultz, M. G., Schulz, M., Venkataraman, C., Zhang, H., Zhang, S., Bellouin, N., Guttikunda, S. K., Hopke, P. K., Jacobson, M. Z., Kaiser, J. W., Klimont, Z., Lohmann, U., Schwarz, J. P., Shindell, D., Storelvmo, T., Warren, S. G., and Zender, C. S.: Bounding the role of black carbon in the climate system: a scientific assessment, J. Geophys. Res.-Atmos., 118, 5380-5552, doi:10.1002/jgrd.50171, 2013.

Capes, G. Johnson, B., McFiggans, G., Williams, P.I., Haywood, J., and Coe, H.: Aging of biomass burning aerosols over West Africa: Aircraft measurements of chemical composition, microphysical properties, and emission ratios, J. Geophys. Res., 113, D00C15, doi:10.1029/2008JD009845, 2008.

Cappa, C. D., Jathar, S. H., Kleeman, M. J., Docherty, K. S., Jimenez, J. L., Seinfeld, J. H., and Wexler, A. S.: Simulating secondary organic aerosol in a regional air quality model using the statistical oxidation model - Part 2: Assessing the influence of vapor wall losses, Atmos. Chem. Phys., 16, 3041-3059, doi:10.5194/acp-16-3041-2016, 2016

Cochrane, M. A., Moran, C. J., Wimberly, M.C., Baer, A. D., Finney, M. A., Beckendorf, K. L., Eidenshink J., and Zhu, Z.: Estimation of wildfire size and risk changes due to fuels treatments, Int. J. Wildland Fire, 21, 357-367, 2012.

Crump, J. G. and Seinfeld, J. H.: Turbulent deposition and gravitational sedimentation of an aerosol in a vessel of arbitrary shape, J. Aerosol Sci., 12, 405-415, doi:10.1016/0021-8502(81)900367, 1981

Cubison, M. J., Ortega, A. M., Hayes, P. L., Farmer, D. K., Day, D., Lechner, M. J., Brune, W. H., Apel, E., Diskin, G. S., Fisher, J. A., Fuelberg, H. E., Hecobian, A., Knapp, D. J., Mikoviny, T., Riemer, D., Sachse, G. W., Sessions, W., Weber, R. J., Weinheimer, A. J., Wisthaler, A., and Jimenez, J. L.: Effects of aging on organic aerosol from open biomass burning smoke in aircraft and laboratory studies, Atmos. Chem. Phys., 11, 12049-12064, doi:10.5194/acp-11-12049-2011, 2011.

DeCarlo, P. F., Ulbrich, I. M., Crounse, J., de Foy, B., Dunlea, E. J., Aiken, A. C., Knapp, D., Weinheimer, A. J., Campos, T., Wennberg, P. O., and Jimenez, J. L.: Investigation of the sources and processing of organic aerosol over the Central Mex- ican Plateau from aircraft measurements during MILAGRO, Atmos. Chem. Phys., 10, 5257-5280, doi:10.5194/acp-10-52572010, 2010.

Donahue, N. M., Robinson, A. L., Stanier, C. O., and Pandis, S. N.: Coupled partitioning, dilution, and chemical aging of semivolatile organics, Environ. Sci. Technol., 40, 2635-2643, doi:10.1021/es052297c, 2006.

Grieshop, A. P., Logue, J. M., Donahue, N. M., and Robinson, A. L.: Laboratory investigation of photochemical oxidation of organic aerosol from wood fires 1: measurement and simulation of organic aerosol evolution, Atmos. Chem. Phys., 9, 1263-1277, doi:10.5194/acp-9-1263-2009, 2009.

Hatch, L. E., Yokelson, R. J., Stockwell, C. E., Veres, P. R., Simpson, I. J., Blake, D. R., Orlando, J. J., and Barsanti, K. C.: Multiinstrument comparison and compilation of non-methane organic gas emissions from biomass burning and implications for smokederived secondary organic aerosol precursors, Atmos. Chem. Phys., 17, 1471-1489, doi:10.5194/acp-17-1471-2017, 2017.

Heilman, W.E., Liu, Y.Q., Urbanski, S., Kovalev, V., and Mickler, R.: Wildland fire emissions, carbon, and climate: plume transport, and chemistry processes, Forest Ecol. Manage., 317, 70-79, doi:10.1016/J.FORECO.2013.02.001, 2014.

Hennigan, C. J., Miracolo, M. A., Engelhart, G. J., May, A. A., Presto, A. A., Lee, T., Sullivan, A. P., McMeeking, G. R., Coe, H., Wold, C. E., Hao, W.-M., Gilman, J. B., Kuster, W. C., de Gouw, J., Schichtel, B. A., Collett Jr., J. L., Kreidenweis, S. M., and Robinson, A. L.: Chemical and physical transformations of organic aerosol from the photo-oxidation of open biomass burning emissions in an environmental chamber, Atmos. Chem. Phys., 11, 7669-7686, doi:10.5194/acp-11-7669-2011, 2011.

Jaffe, D. A. and Wigder, N. L. : Ozone production from wildfires: A critical review, Atmos. Environ., 51, 1-10, 2012.

Jassen, N. A. H., Gerlofs-Nijland, M. E., Lanki, T., Salonen, R. O., Cassee, F., Hoek, G., Fischer, P., Brunekreef, B., and Krzyzonowsk, M.: Health Effects of Black Carbon, World Health Organization, Regional Office for Europe, available at: http://www.euro.who.int/_data/assets/pdf_ file/0004/162535/e96541.pdf (last access: April 2017), 2010.

Jathar, S. H., Donahue, N. M., Adams, P. J., and Robinson, A. L.: Testing secondary organic aerosol models using smog chamber data for complex precursor mixtures: influence of precursor volatility and molecular structure, Atmos. Chem. Phys., 14, 5771-5780, doi:10.5194/acp-14-5771-2014, 2014.

Jathar, S. H., Gordon, T. D., Hennigan, C. J., Pye, H. O. T., Pouliot, G., Adams, P. J., Donahue, N. M., and Robinson: Unspeciated organic emissions from combustion sources and their influence on the secondary organic aerosol budget in the United States, P. Natl. Acad. Sci. USA, 10473-10478, doi:10.1073/pnas.1323740111, 2014.

Jimenez, J. L., Canagaratna, M. R., Donahue, N. M., Prevot, A. S. H., Zhang, Q., Kroll, J. H., DeCarlo, P. F., Allan, J. D., Coe, H., Ng, N. L., Aiken, A. C., Docherty, K. S., Ulbrich, I. M., Grieshop, A. P., Robinson, A. L., Duplissy, J., Smith, J. D., Wilson, K. R., Lanz, V. A., Hueglin, C., Sun, Y. L., Tian, J., Laaksonen, A., Raatikainen, T., Rautiainen, J., Vaattovaara, P., Ehn, M., Kulmala, M., Tomlinson, J. M., Collins, D. R., Cubison, D. R., Dunlea, E. J., Huffman, J. A., Onasch, T. B., Alfarra, M. R., Williams, P. I., Bower, K., Kondo, Y., Schneider, J., Drewnick, F., Borrmann, S., Weimer, S., Demerjian, K., 
Salcedo, D., Cottrell, L., Griffin, R., Takami, A., Miyoshi, T., Hatakeyama, S., Shimono, A., Sun, J. Y., Zhang, Y. M., Dzepina, K., Kimmel, J. R., Sueper, D., Jayne, J. T., Herndon, S. C., Trimborn, A. M., Williams, L. R., Wood, E. C., Middlebrook, A. M., Kolb, C. E., Baltensperger, U., and Worsnop, D. R.: Evolution of organic aerosols in the atmosphere, Science, 326, 1525-1529, doi:10.1126/science.1180353, 2009.

Johnston, F. H., Henderson, S. B., Chen, Y., Randerson, J. T., Marlier, M., DeFries, R. S., Kinney, P., Bowman, D. M. J. S., and Brauer, M.: Estimated global mortality attributable to smoke from landscape fires, Environ. Health Persp., 120, 695-701, doi:10.1289/ehp.1104422, 2012.

Jolleys, M. D., Coe, H., McFiggans, G., Capes, G., Allan, J. D., Crosier, J., Williams, P. I., Allen, G., Bower, K. N., Jimenez, J. L., Russell, L. M., Grutter, M., and Baumgardner, D.: Characterizing the aging of biomass burning organic aerosol of mixing ratios, Environ. Sci. Technol., 46, 1309313102, doi:10.1021/es302386v, 2012.

Jolleys, M. D., Coe, H., McFiggans, G., McMeeking, G. R., Lee, T., Kreidenweis, S. M., Collectt Jr., J. L., and Sullivan A. P.: Organic aerosol emission ratios from the laboratory combustion of biomass fuels, J. Geophys. Res.-Atmos., 119, 12850-12871, doi:10.1002/2014JD021589, 2014.

Jolleys, M. D., Coe, H., McFiggans, G., Taylor, J. W., O’Shea, S. J., Le Breton, M., Bauguitte, S. J.-B., Moller, S., Di Carlo, P., Aruffo, E., Palmer, P. I., Lee, J. D., Percival, C. J., and Gallagher, M. W.: Properties and evolution of biomass burning organic aerosol from Canadian boreal forest fires, Atmos. Chem. Phys., 15, 3077-3095, doi:10.5194/acp-15-3077-2015, 2015.

Klug, W.: A method for determining diffusion conditions from synoptic observations, Staub-Reinhalt. Luft, 29, 14-20, 1969.

Kokkola, H., Yli-Pirilä, P., Vesterinen, M., Korhonen, H., Keskinen, H., Romakkaniemi, S., Hao, L., Kortelainen, A., Joutsensaari, J., Worsnop, D. R., Virtanen, A., and Lehtinen, K. E. J.: The role of low volatile organics on secondary organic aerosol formation, Atmos. Chem. Phys., 14, 1689-1700, doi:10.5194/acp-14-16892014, 2014.

Krechmer, J. E. Pagonis, D. P., Ziemann, P. J., and Jimenez, J. L. L.: Quantification of gas-wall partitioning in Teflon environmental chambers using rapid bursts of low-volatility oxidized species generated in-situ, Environ. Sci. Technol., 50, 5757-5765, doi:10.1021/acs.est.6b00606, 2016.

La, Y. S., Camredon, M., Ziemann, P. J., Valorso, R., Matsunaga, A., Lannuque, V., Lee-Taylor, J., Hodzic, A., Madronich, S., and Aumont, B.: Impact of chamber wall loss of gaseous organic compounds on secondary organic aerosol formation: explicit modeling of SOA formation from alkane and alkene oxidation, Atmos. Chem. Phys., 16, 1417-1431, doi:10.5194/acp-161417-2016, 2016.

Lim, Y. B. and Ziemann, P. J.: Effects of Molecular Structure on Aerosol Yields from OH Radical-Initiated Reactions of Linear, Branched, and Cyclic Alkanes in the Presence of $\mathrm{NO}_{x}$, Environ. Sci. Technol., 43, 2328-2334, doi:10.1021/es803389s, 2009.

Mason, S.A., Trentmann, J., Winterrath, T., Yokelson, R. J., Christian, T. J., Carlson, Lm J., Warner, T. R., Wolfe, L. C., and Andreae, M. O.: Intercomparison of Two Box Models of the Chemical Evolution in Biomass-Burning Smoke Plumes, J. Atmos. Chem., 55, 273-297, 2001.
Matsunaga, A. and Ziemann, P. J.: Gas-wall partitioning of organic compounds in a teflon film chamber and potential effects on reaction product and aerosol yield measurements, Aerosol Sci. Tech., 44, 881-892, doi:10.1080/02786826.2010.501044, 2010.

May, A. A., Levin, E. J. T., Hennigan, C. J., Riipinen, I., Lee, T., Collett, J. L., Jimenez, J. L., Kreidenweis, S. M., and Robinson, A. L.: Gas-particle partitioning of primary organic aerosol emissions: 3. Biomass burning, J. Geophys. Res.-Atmos., 118, 11327-11338, doi:10.1002/jgrd.50828, 2013.

May, A. A., McMeeking, G. R., Lee, T., Taylor, J. W., Craven, J. S., Burling, I., Sullivan, A. P., Akagi, S., Collett Jr., J. L., Flynn, M., Coe, H., Urbanski, S. P., Seinfeld, J. H., Yokelson, R. J., and Kreidenweis, S. M.: Aerosol emissions from prescribed fires in the United States: A synthesis of laboratory and aircraft measurements, J. Geophys. Res.-Atmos., 119, 1182611849, doi:10.1002/2014JD021848, 2014.

May, A. A., Lee, T., McMeeking, G. R., Akagi, S., Sullivan, A. P., Urbanski, S., Yokelson, R. J., and Kreidenweis, S. M.: Observations and analysis of organic aerosol evolution in some prescribed fire smoke plumes, Atmos. Chem. Phys., 15, 6323-6335, doi:10.5194/acp-15-6323-2015, 2015.

McMurry, P. H. and Grosjean, D.: Gas and aerosol wall losses in Teflon film smog chambers, Environ. Sci. Technol., 19, 11761182, doi:10.1021/es00142a006, 1985.

McVay, R. C., Cappa, C. D., and Seinfeld, J. H.: Vapo-wall deposition in chambers: theoretical considerations, Environ. Sci. Technol., 48, 10251-10258, doi:10.1021/es502170j, 2014.

Mok, J., Krotkov, N. A., Arola, A., Torres, O., Jethva, H., Andrade, M., Labow, G., Eck, T. F., Li, Z., Dickerson, R. R., Stenchikov, G. L., Stenchikov, G. L., Osipov, S., and Ren, X.: Impacts of brown carbon from biomass burning on surface UV and ozone photochemistry in the Amazon Basis, Sci. Rep., 6, 36940, doi:10.1038/srep36940, 2016.

Naeher, L. P., Brauer, M., Lipsette M., Zelikoff, J. T., Simpson, C. D., Koenig, J. Q., and Smith, K. R.: Woodsmoke health effects: a review, Inhal. Toxicol., 19, 67-106, doi:10.1080/08958370600985875, 2007.

Nah, T., McVay, R. C., Zhang, X., Boyd, C. M., Seinfeld, J. H., and $\mathrm{Ng}, \mathrm{N}$. L.: Influence of seed aerosol surface area and oxidation rate on vapor wall deposition and SOA mass yields: a case study with $\alpha$-pinene ozonolysis, Atmos. Chem. Phys., 16, 9361-9379, doi:10.5194/acp-16-9361-2016, 2016.

Ortega, A. M., Day, D. A., Cubison, M. J., Brune, W. H., Bon, D., de Gouw, J. A., and Jimenez, J. L.: Secondary organic aerosol formation and primary organic aerosol oxidation from biomass-burning smoke in a flow reactor during FLAME-3, Atmos. Chem. Phys., 13, 11551-11571, doi:10.5194/acp-1311551-2013, 2013.

Pankow, J. F.: An absorption model of gas/particle partitioning of organic compounds in the atmosphere, Atmos. Environ., 28, 185-188, 1994.

Pierce, J. R. and Adams, P. J.: A computationally efficient aerosol nucleation/condensation method: pseudo-steadystate sulfuric acid, Aerosol Sci. Tech., 43, 216-226, doi:10.1080/02786820802587896, 2009.

Pierce, J. R., Engelhart, G. J., Hildebrandt, L., Weitkamp, E. A., Pathak, R. K., Donahue, N. M., Robinson, A. L., Adams, P. J., and Pandis, S. N.: Constraining particle evolution from wall losses, coagulation, and condensation-evaporation in smog 
chamber experiments: optimal estimation based on size distribution measurements, Aerosol Sci. Tech., 42, 1001-1015, doi:10.1080/02786820802389251, 2008.

Roberts, G., Wooster, M. J., and Lagoudakis, E.: Annual and diurnal african biomass burning temporal dynamics, Biogeosciences, 6 , 849-866, doi:10.5194/bg-6-849-2009, 2009.

Sakamoto, K. M., Laing, J. R., Stevens, R. G., Jaffe, D. A., and Pierce, J. R.: The evolution of biomass-burning aerosol size distributions due to coagulation: dependence on fire and meteorological details and parameterization, Atmos. Chem. Phys., 16, 7709-7724, doi:10.5194/acp-16-7709-2016, 2016.

Springsteen, B., Christofk, T, York, R. A., Mason, T., Baker, S., Lincoln, E., Hartsough, B., and Yoshioka, T.: Forest biomass diversion in the Sierra Nevada: Energy, economics and emissions, Calif. Agric., 69, 142-149, doi:10.3733/ca.v069n03p142, 2015.

Weitkamp, E. A., Sage, A. M., Pierce, J. R., Donahue, N. M., and Robinson, A. L.: Organic aerosol formation from photochemical oxidation of diesel exhaust in a smog chamber, Environ. Sci. Technol., 41, 6969-6975, doi:10.1021/es070193r, 2007.

Yeh, G. K. and Ziemann, P. J.: Alkyl nitrate formation from the reactions of $\mathrm{C} 8-\mathrm{C} 14 \mathrm{n}$-Alkanes with $\mathrm{OH}$ Radicals in the Presence of $\mathrm{NO}_{x}$ : measured yields with essential corrections for gas-wall partitioning, J. Phys. Chem. A, 118, 8147-8157, doi:10.1021/jp500631v, 2014.

Yokelson, R. J., Bertschi, I. T., Christian, T. J., Hobbs, P. V., Ward, D. E., and Hao, W. M.: Trace gas measurements in nascent, aged, and cloud-processed smoke from African savanna fires by airborne Fourier transform infrared spectroscopy (AFTIR), J. Geophys. Res., 108, 2156-2202, doi:10.1029/2002JD002322, 2003.
Yokelson, R. J., Crounse, J. D., DeCarlo, P. F., Karl, T., Urbanski, S., Atlas, E., Campos, T., Shinozuka, Y., Kapustin, V., Clarke, A. D., Weinheimer, A., Knapp, D. J., Montzka, D. D., Holloway, J., Weibring, P., Flocke, F., Zheng, W., Toohey, D., Wennberg, P. O., Wiedinmyer, C., Mauldin, L., Fried, A., Richter, D., Walega, J., Jimenez, J. L., Adachi, K., Buseck, P. R., Hall, S. R., and Shetter, R.: Emissions from biomass burning in the Yucatan, Atmos. Chem. Phys., 9, 5785-5812, doi:10.5194/acp-9-5785-2009, 2009.

Zhang, X., Cappa, C. D., Jathar, S. H., McVay, R. C., Ensberg, J. J., Kleeman, M. J., and Seinfeld, J. H.: Influence of vapor wall loss in laboratory chambers on yields of secondary organic aerosol, P. Natl. Acad. Sci. USA, 111, 5802-5807, doi:10.1073/pnas.1404727111, 2014.

Zhang, X. and Kondragunta, S.: Temporal and spatial variability in biomass burned areas across the USA derived from the GOES fire product, Remote Sens. Environ., 112, 2886-2897, 2008.

Zhang, X., Schwantes, R. H., McVay, R. C., Lignell, H., Coggon, M. M., Flagan, R. C., and Seinfeld, J. H.: Vapor wall deposition in Teflon chambers, Atmos. Chem. Phys., 15, 4197-4214, doi:10.5194/acp-15-4197-2015, 2015. 